\title{
Geochemical characteristics of biotite from felsic intrusive rocks around the Sisson Brook W-Mo-Cu deposit, west-central New Brunswick: an indicator of halogen and oxygen fugacity of magmatic systems
}

\author{
Wei Zhang $^{\text {a* }}$, David R. Lentz ${ }^{a}$, Kathleen G. Thorne ${ }^{b}$, Christopher McFarlane ${ }^{a}$ \\ a Department of Geology, University of New Brunswick, New Brunswick, Fredericton E3B 5A3, Canada \\ ${ }^{\mathrm{b}}$ Geological Surveys Branch, New Brunswick Department of Energy and mines, New Brunswick, \\ Fredericton E3B 5H1, Canada
}

\begin{abstract}
The Sisson Brook W-Mo-Cu deposit was formed by hydrothermal fluids likely related to the Nashwaak Granites (muscovite-biotite granite, Group I; and biotite granite, Group II) and related dykes (biotite granitic dykes, Group III, and a feldspar-biotitequartz porphyry dyke, Group IV). Chemical data obtained using EPMA and LA-ICP-MS data of primary magmatic biotites were used to investigate magmatic processes and associated hydrothermal fluids.

Trace element features of biotite in Group I two-mica granite suggest more magmatic processes along with a simple fractional crystallization. The $\mathrm{K} / \mathrm{Rb}$ ratios and compatible elements $(\mathrm{Cr}, \mathrm{Ti}, \mathrm{Co}, \mathrm{V}$, and $\mathrm{Ba})$ in biotite from Groups II, III, and IV decreases, whereas incompatible elements including Ta, Tl, Ga, Cs, Li, and $\mathrm{Sn}$ increase with magma fractionation. No correlation of $\mathrm{Cu}, \mathrm{W}$ and $\mathrm{Mo}$ with $\mathrm{K} / \mathrm{Rb}$ ratios is evident,

\footnotetext{
${ }^{*}$ Corresponding author.

E-mail address: wei.z@unb.ca (W. Zhang).
} 
suggesting that partitioning of $\mathrm{Cu}, \mathrm{W}$, and Mo into biotite may not be entirely controlled by magma fractionation.

Halogen fugacity of the parental magma of the Nashwaak Granites and related dykes, calculated from zircon saturation temperature, shows that Group I has high $\mathrm{fHF} / f \mathrm{Cl}$ ratio (broadly higher than 0 ), similar to the plutons at the Henderson porphyry Mo deposit. The $f \mathrm{HF} / f \mathrm{Cl}$ ratios of the other groups are generally lower than 0 , comparable to the Santa Rita porphyry $\mathrm{Cu}$ deposit. The $f \mathrm{H}_{2} \mathrm{O} / \mathrm{fHCl}$ and $f \mathrm{H}_{2} \mathrm{O} / f \mathrm{HF}$ ratios inferred from biotite in the Nashwaak Granites and related dykes are from 3 to 5 and from 4 to 5 , respectively. The inferred oxygen fugacity shows the dyke phases (Groups III and IV) have an oxygen fugacity around the nickel-nickel oxide buffer. The plutonic phases (Groups I and II) have the oxygen fugacity around the quartz-fayalite-magnetite (QFM) buffer at high temperatures and oxidized to nickel-nickel oxide buffer at lower temperatures. This oxidation process in the plutonic phases (Groups I and II) could be caused by $\mathrm{H}_{2}$ release at or near $\mathrm{H}_{2} \mathrm{O}$ vapour saturation at high $\mathrm{H}_{2} \mathrm{O} / \mathrm{Fe}^{2+}$. The magma associated with the biotite dykes (Group III) is more likely the source of the hydrothermal fluids at the Sisson Brook deposit since it has the highest differentiation degree and seems to have formed in an oxidized setting, necessary for Mo to concentrate in the late stage fluids.

Key words: Biotite mineral chemistry, LA-ICP-MS, Sisson Brook W-Mo deposit, Halogen fugacity, Oxygen fugacity 


\section{Introduction}

The Sisson Brook W-Mo-Cu deposit, situated in west-central New Brunswick, is hosted by the Cambro-Ordovician volcanic and sedimentary rocks of the Miramichi and Tetagouche groups (Fig. 1). Rennie (2012) defined this deposit as an intrusion-related, structurally controlled, bulk tonnage tungsten-molybdenum deposit whose hydrothermal features are generally similar to porphyry copper deposits. The Sisson Brook deposit is similar to other W-Mo deposits in New Brunswick, such as the Mount Pleasant (W-MoBi and Sn-Zn-In, ca. 370 Ma, Re-Os molybdenite; Thorne et al., 2013), Burnthill (W-MoSn), and Lake George (Sb-Au and W-Mo, ca. 412 Ma, U-Pb zircon, McLeod et al., 2003) deposits, as they are genetically linked to magmatic hydrothermal fluids exsolved from felsic batholiths and plutons formed during the Acadian Orogeny. These granitoids are metaluminous to peraluminous and have transitional I-type to A-type granite signatures, which are enriched in incompatible elements and are generally evolved $\left(>65 \% \mathrm{SiO}_{2}\right.$, Kooiman et al., 1986; MacLellan and Taylor, 1989; Yang et al., 2002; Inverno and Hutchinson, 2006). Enrichment of these metallic elements may have resulted from a combination of crystal fractionation followed by aqueous phase saturation and separation, suggested by field and petrographic evidence including the presence of miarolitic cavities and myrmekite (Tucker et al., 1998; McLeod et al., 2003; Yang et al., 2008).

Chemical composition of magmatic biotite is sensitive to chemical and physical factors associated with crystallization of the magma (Munoz, 1992; Abdel-Rahman, 1994) and also to exsolved hydrothermal fluids (Siahcheshm et al., 2012). The interlayer cations $\left(\mathrm{K}^{+}, \mathrm{Na}^{+}, \mathrm{Ca}^{2+}, \mathrm{Ba}^{+}\right.$, and $\left.\mathrm{Cs}^{+}\right)$in biotite crystals could be leached out by later hydrothermal fluids and alteration processes (e.g., chloritization); the octahedral layer 
$\left(\mathrm{Al}^{6+}, \mathrm{Mg}^{2+}, \mathrm{Fe}^{2+}, \mathrm{Fe}^{3+}, \mathrm{Li}^{+}, \mathrm{Ti}^{4+}, \mathrm{Mn}^{2+}, \mathrm{Zn}^{2+}, \mathrm{Cr}^{3+}\right.$, and $\left.\mathrm{V}^{3+}\right)$ and tetrahedral layer cations $\left(\mathrm{Si}^{4+}\right.$ and $\left.\mathrm{Al}^{4+}\right)$ are controlled by complex substitution mechanisms at different $P-T-X$ conditions of a melt (magma) (Fleet, 2003). Abdel-Rahman $(1994,1996)$ suggested that the $\mathrm{MgO}, \mathrm{FeO}$, and $\mathrm{Al}_{2} \mathrm{O}_{3}$ contents of biotite are related to bulk composition of their host rocks. Munoz $(1984,1992)$ showed the $\mathrm{FeO} /(\mathrm{FeO}+\mathrm{MgO})$ ratio of biotite is affected by oxygen fugacity $\left(f \mathrm{O}_{2}\right)$ of the system, which is a critical factor controlling partition behaviour of $\mathrm{W}$ and Mo. In muscovite- and fluorite-free granitoid rocks, biotite contains between 70 and $90 \%$ of the $\mathrm{F}$ and $\mathrm{Cl}$ in the hydroxyl site with the remainder in apatite, amphibole and titanite (Speer, 1984). Chemical equilibrium between biotite and hydrothermal fluids percolating through the rock in the late stages of crystallization makes it possible to calculate the halogen composition of the fluids using composition of biotite (Zhu and Sverjensky, 1991, 1992). This method has been used to study the fluid composition of porphyry $\mathrm{Cu}(\mathrm{Mo}, \mathrm{Au})$ deposits (Loferski and Ayuso, 1995; Selby and Nesbitt, 1997, 2000; Idrus et al., 2007; Ayati et al., 2008), intrusion-related Au deposits (Coulson et al., 2001; Yang and Lentz, 2005; Saravanan et al., 2009), and tungsten deposits (van Middelaar and Keith, 1990; Rasmussen and Mortensen, 2013). In this paper, the partition behaviour of trace element into biotite during magma crystallization, as well as halogen and oxygen fugacity in the magmatic system associated with the Nashwaak Granites and related dykes will be investigated by analyzing composition of biotite in these rock units. The results of this study are helpful to identify the rock unit that is more likely to have exsolved the hydrothermal fluids associated with the W-Mo mineralization of the Sisson Brook deposit. 


\section{Geological setting}

The rocks in the vicinity of the Sisson Brook deposit consist of a thick sequence of Cambro-Ordovician continental and marine volcanic and sedimentary rocks and younger mafic and felsic intrusive rocks (Nashwaak Granites, Howard Peak granodiorite and gabbro) (Fig. 1).

The oldest rocks are quartzose wackes interbedded with siltstones and shales of the Cambrian-Early Ordovician Miramichi Group, which occur in the core of a northnortheast-trending, southerly plunging anticline in the area (Lutes, 1981). These rocks are bound to the east and west by younger volcanic and sedimentary rocks of the Ordovician Tetagouche Group (Fig. 1). To the west, the Miramichi Group rocks are in fault contact with felsic crystal tuffs, mafic tuffs, and clastic sedimentary rocks of the Ordovician Turnbull Mountain Formation, and to the east, they are overlain unconformably by black shales, flow-banded felsic volcanic rocks and fragmental mafic volcanic rocks of the Ordovician Hayden Lake Formation.

The oldest intrusive pluton in the Sisson Brook area is the Howard Peak Granodiorite dated at 432.1 $\pm 1.9 \mathrm{Ma}$ using $\mathrm{U}-\mathrm{Pb}$ titanite geochronology (Bustard, 2013). This granodiorite is dark grey, medium- to coarse-grained, and consists primarily of plagioclase feldspar, with $25-35 \%$ hornblende, and 5\% quartz. It also contains accessory potassium feldspar, hematized magnetite, titanite, apatite, and zircon (Rennie, 2012). The Howard Peak Granodiorite is foliated and marked by segregations of metamorphic biotite, which formed by intrusion of the Nashwaak Granites on its west margin. The Howard Peak Granodiorite grades eastward into, and becomes intermixed with dark grey, 
medium-grained ophitic gabbro. Its eastern contact with the Turnbull Mountain Formation is a vertical fault (Fyffe et al., 2008).

The Nashwaak Granites are the unfoliated Acadian granites in the Central Plutonic Belt of New Brunswick and covers an area of $250 \mathrm{~km}^{2}$, extending from Spruce Peak northwards to McKiel Brook. On its east side, the Nashwaak Granites intrude the Miramichi Group, Tetagouche Group, and the Howard Peak Granodiorite. Andalusite and cordierite are present in sedimentary rocks up to $2 \mathrm{~km}$ from the contact. This constrains the level of exposure to approximately $10 \mathrm{~km}$ (Turner, 1981). To the north, then intrude the Cambro-Ordovician Trousers Lake Metamorphic Suite, which contains sillimanite within $1 \mathrm{~km}$ of the contact with the Ordovician McKiel Lake Granite. To the west, they intrude the Becaguimec Lake Gabbro. The contact between the Nashwaak Granites and Early Devonian volcanic rocks to the south is not exposed, but is likely intrusive. The Nashwaak Granites have two subfacies: (1) pink, coarse- to medium-grained, equigranular to subporphyritic biotite granite with a mineral assemblage of plagioclase, orthoclase, quartz, and minor biotite, that grades northward into (2) muscovite-biotite granite. In drill core, foliated, silicified and greisenized granite dykes containing xenoliths of gabbro crosscut the Howard Peak Granodiorite.

A grey, massive, unfoliated granite porphyry dyke was intersected in drill hole SSN26. The phenocrysts are plagioclase, biotite, and quartz. A U-Pb age of $364.5 \pm 1.8$ Ma from zircon has been determined for this dyke (Fyffe et al., 2008).

The Sisson Brook deposit has three mineralized zones (Fig. 2), in which Zones I and II are structurally controlled and reach over tens of metres in width and about a hundred metres along strike. These zones contain $\mathrm{W}$ and $\mathrm{Cu}$, but no significant $\mathrm{Mo}$ was observed. 
Zone III contains the main W and Mo resource for the Sisson Brook deposit. The latest mineral resource estimate shows this deposit has $387 \mathrm{Mt}$ of ore grading $0.067 \% \mathrm{WO}_{3}$ and $0.021 \%$ Mo in the measured-plus the indicated category, and $187 \mathrm{Mt}$ of ore grading $0.05 \% \mathrm{WO}_{3}$ and $0.02 \% \mathrm{Mo}$ in inferred category (Rennie, 2012).

\section{Source of data, specimens and analytical methods}

In fresh or least-altered Nashwaak Granites and related dykes, six samples of twomica granite, seven samples of biotite granite, seven samples of biotite granitic dykes, and one sample of porphyry dyke, were collected and prepared for the biotite analysis by electron probe micro analysis (EPMA) at the University of New Brunswick. The samples were analyzed using a $15 \mathrm{kV}$ accelerating voltage, $10 \mathrm{nA}$ beam current, and a maximum 40s counting interval. The analysis was conducted in wavelength-dispersion mode on a JXA JEOL-733 probe, equipped with dQant32 and dSpec automation from Geller Microanalytical Laboratories. Halogen elements $\mathrm{F}$, and $\mathrm{Cl}$ of biotite from different groups were determined by EPMA. These samples were then analyzed at the same spots in each biotite grain by laser ablation-inductively coupled plasma-mass spectrometry (LA-ICP-MS) which was conducted using a Resonetics M-50-LR 193nm Excimer laser ablation system coupled to an Agilent 7700x quadrupole ICP-MS also at the University of New Brunswick. The analysis used $64 \mu \mathrm{m}$ beam size, $4.5 \mathrm{~Hz}$ pulse rate, $4 \mathrm{~J} / \mathrm{cm}^{2}$ energy. The Al content of each spot measured EPMA was used with an internallystandardized data reduction scheme in order to obtain the most accurate trace element data (Appendix Table A). The GOR128-G and NIST612 glass were used as the reference material in order to confirm the precision and accuracy of the results of the LA-ICP-MS analysis. The relative standard deviations (\%RSD) for the most of trace elements in 
GOR128-G and NIST612 are lower than 4\% (See Appendix Table B). The relative deviations for trace elements in them are generally within 10\% (see Appendix Table B). Detailed analytical results and limits of detection are in Appendix Table C and D. Formula calculation of biotite is based on 22 atoms of oxygen by the EPMA data. Water contents were calculated by stoichiometry (cf. Yang and Lentz, 2005).

\section{Petrography}

The studied samples can be grouped based upon their geological occurrences and mineral assemblages. Group I is muscovite-biotite phase of the Nashwaak Granites that is fine- to coarse-grained $(0.5-7 \mathrm{~mm})$, seriate textured, and is characterized by the presence of biotite with variable muscovite contents. Biotite $(0.5-2 \mathrm{~mm})$ is euhedral to anhedral, containing mineral inclusions of zircon and apatite. Apatite also occurs in feldspar with moderate to high relief and low birefringence (Fig. 3a). Microcline with predominantly patchy tartan twins is present. Plagioclase displays typical polysynthetic twinning and/or Carlsbad twins. Some small earlier formed plagioclase with altered cores (not resorbed) and K-feldspar rims are contained in large perthite (Fig. 3b). Large (3 mm) euhedral crystals of plagioclase are zoned and are altered along the boundary of each growth zone (Fig. 3c). This concentric zoing of plagioclase consists of a core formed at a high temperature with enriched $\mathrm{Ca}$ and $\mathrm{Al}$, and a rim crystallized at a lower temperature with more $\mathrm{Na}$ and $\mathrm{Si}$, as determined by well-known experiments on plagioclase crystallization (Lofgren, 1974, 1980).

Group II is biotite granitic phase of the Nashwaak Granites, which is fine- to coarsegrained $(0.5-6 \mathrm{~mm})$. Biotite is abundant (approximately $20 \%, 0.5-1.5 \mathrm{~mm}$ ) in the samples of Group II, associated with accessory minerals consisting of zircon, apatite, 
monazite, and opaque magnetite, and ilmenite. Zircon and apatite commonly occur in biotite clusters. Biotite inclusions are also found in large quartz grains (Fig. 3d). Anhedral quartz and alkali feldspar intergrowth formed granophyre texture suggests water saturation during crystallization (Fig. 3e; Yang and Lentz, 2005). Microcline with tartan twins is common is consistent with water saturation and slow cooling. Plagioclase with altered cores and magmatic rims are present inside microcline or between quartz and feldspar grains, similar to that observed in the muscovite-biotite granite (Group I).

Biotite granitic dykes (Group III) crosscut the Howard Peak diorite-gabbro observed in drill core. These dykes range in width from several $\mathrm{cm}$ up to $12.2 \mathrm{~m}$, generally exhibiting sharp contacts with the host although locally, irregular with angles from $20^{\circ}$ to $80^{\circ}$ to the core axis (holes drilled at a dip angle of $45^{\circ}$ with a few at $\left.55^{\circ}\right)($ Geodex Minerals Ltd. drill logs). The dyke samples are generally light greenish grey in color, fine- to coarse-grained $(0.5-5 \mathrm{~mm})$, allotriomorphic inequigranular and unfoliated. This group generally has the same mineral composition as the biotite granite with the exception of the presence of some secondary minerals (i.e., pyrite and chalcopyrite). Biotite is altered to chlorite along their rims and cleavages. Unaltered or relatively fresh biotite is anhedral (typically $<1 \mathrm{~mm}$ ) and is in contact with plagioclase that shows both Albite and Carlsbad twins (Fig. 3f). No plagioclase zoning was observed. Magmatic, anhedral quartz is more abundant than in the Group II samples, and equant subgrains in deformed quartz was also seen in several samples.

Group IV is a quartz-biotite-feldspar porphyry dyke that was intersected from 13.6 to $54.6 \mathrm{~m}$ in drillhole SSN-26. The granite porphyry contains about 50\% phenocrysts set in a fine-grained groundmass of alkali feldspar and quartz. The phenocrysts population 
includes about $25 \%$ zoned plagioclase laths $\left(\mathrm{An}_{34}-\mathrm{An}_{15}\right)$ up to $1 \mathrm{~cm}$ in length, $10 \%$ euhedral to subhedral (i.e. resorption texture with embayed outline or habits of $\beta$-quartz polymorph, Fig. 3g) quartz crystals from 1 to $7 \mathrm{~mm}$ in width, $8 \%$ biotite laths ranging from 0.05 to $1 \mathrm{~cm}$ in length, and $7 \%$ alkali feldspar crystals from 0.2 to $1.0 \mathrm{~cm}$ in width (Mann, 1980; Nast, 1985; Nast and Williams-Jones, 1991). Plagioclase crystals are zoned and some have Albite twins. The biotite is euhedral and some have slight alteration along their rims (Fig. 3h).

\section{Biotite mineral chemistry}

\subsection{Biotite classification}

It is critical to be sure that biotite grains analyzed are of primary magmatic origin, so that their chemical composition may reflect magmatic conditions of crystallization. The Ti content of biotite is thermally controlled (Patiño Douce, 1993; Stussi and Cuney, 1996). Re-equilibrated and neoformed biotite grains, resulting from low temperature hydrothermal alteration, have less Ti than those of primary magmatic biotites. Most of the biotites from the Nashwaak Granites and related dykes plot in the primary biotite domain defined by Nachit et al. (2005) with the $\mathrm{TiO}_{2}$ ranging from 1.76 to $4.55 \mathrm{wt} \%$. The Ti (apfu, atoms per formula unit) of the biotite from Group II (mean Ti $=0.42)$ and Group IV (mean $\mathrm{Ti}=0.46$ ) are generally higher than that of the biotite from Group I (mean $\mathrm{Ti}=0.32)$ and Group III (mean $\mathrm{Ti}=0.3)($ Fig. 4a, Table 1). Aluminum content of biotite crystallized in equilibrium with a silicate melt reflects the peraluminosity of the melt (Stussi and Cuney, 1996) and it is commonly the host for the excess Al in peraluminous granitoids (Fleet, 2003). Therefore, biotite from the two-mica granite (Group I, whole rock aluminum saturation index $>1.1$, Zhang, 2015) has higher Al 
(apfu>3.1) than that of biotite from other groups (whole rock ASI $<1.1$, Zhang, 2015)

(Fig. 4b). In the International Mineralogical Association (IMA) classification diagram, the most of the biotites plot close to the siderophyllite-eastonite boundary (Rieder et al., 1998 ) with the $\mathrm{Fe} /(\mathrm{Fe}+\mathrm{Mg}$ ) ratio between 0.49 and 0.74 (Fig. 4c). In the study of AbdelRahman (1994) on the composition of biotite from various igneous rock types, he concluded that biotites in alkaline anorogenic suites are mostly iron-rich, biotites in peraluminous (including S-type) suites are siderophyllitic in composition, and those in calc-alkaline, mostly subduction-related orogenic suites are enriched in $\mathrm{Mg}$. In the $\mathrm{MgO}-$ $\mathrm{FeO}+\mathrm{MnO}-\mathrm{Al}_{2} \mathrm{O}_{3}$ diagram (Fig. 4b; after Abdel-Rahman, 1994), most of the biotites of Nashwaak Granites and related dykes plot on the border between calc-alkaline and peraluminous suites. This conclusion is supported by using plots of the inverse correlation between the $\mathrm{Al}$ and $\mathrm{Mg}$ a.p.f.u. contents of these biotites (Nachit et al., 1985). Stussi and Cuney (1996) explained that the most fractionated members of calc-alkaline magmas may become slightly to moderately peraluminous although it is well-established that the origin of most peraluminous granites is known to be different than that of calcalkaline magmas.

\subsection{Trace-element characteristics}

Tischendorf et al. (1997, 2001) investigated the trace elements (Ti, Sn, Sc, V, Cr, Ga, $\mathrm{Mn}, \mathrm{Co}, \mathrm{Ni}, \mathrm{Zn}, \mathrm{Sr}, \mathrm{Ba}, \mathrm{Rb}, \mathrm{Cs}$ ) in micas of the system phlogopite-annite-siderophyllitepolylithionite (PASP) and divided the micas into seven varieties by the parameter mgli (=octahedral Mg minus Li). However, if the $\mathrm{Ba}, \mathrm{Mg}, \mathrm{Fe}, \mathrm{Ni}, \mathrm{Co}, \mathrm{Sc}, \mathrm{V}, \mathrm{Cr}, \mathrm{Ti}, \mathrm{Be} / \mathrm{Rb}$ and $\mathrm{K} / \mathrm{Rb}$ all decrease in biotite, whereas $\mathrm{Li}, \mathrm{Rb}, \mathrm{Cs}, \mathrm{Tl}, \mathrm{Be}, \mathrm{Sn}$ and $\mathrm{Fe} / \mathrm{Mg}$ increase in biotite with magmatic fractionation as suggested by Gordiyenko (1975), then the parameter mgli 
may be substituted by $\mathrm{K} / \mathrm{Rb}$ as an indicator of the magma evolution as this ratio decreases with fractionation.

The $\mathrm{K} / \mathrm{Rb}$ ratios of biotite from the Nashwaak Granites and related dykes decrease gradually from porphyry dykes (Group IV, 148 to 219), to the biotite granite (Group II, 74 to 163), the biotite granitic dykes (Group III, 92 to 108), and two-mica granite (Group I, 33 to 112) (Table 2, Appendix Table D, Fig. 5). The same trend is observed for the compatible elements (in felsic rocks) $\mathrm{Cr}$ (12 to $97 \mathrm{ppm}$ ), Ti (1.19 to $2.89 \mathrm{wt} . \%$ ), Co (19 to $61 \mathrm{ppm}$ ), V (38 to $463 \mathrm{ppm}$ ), and Ba (30 to $2423 \mathrm{ppm}$ ) in Groups II, III, and IV. Group I deviates slightly from this trend with $\mathrm{Cr}$ contents values between 39 to $186 \mathrm{ppm}$, Ti from 0.9 to 1.9 wt.\%, Co from 26 to $42 \mathrm{ppm}, \mathrm{V}$ between 96 and $309 \mathrm{ppm}$, and $\mathrm{Ba}$ of 12 to 1420 ppm. Nickel in those biotites is scattered and ranges from $6 \mathrm{ppm}$ to $64 \mathrm{ppm}$. The incompatible elements, Ta (2-76 ppm), Tl (2-14 ppm), Ga (44-140 ppm), Cs (8-651 ppm), and Li (105-1282 ppm), show a reverse distribution pattern and increase continuously from the porphyry dykes, to biotite granite, biotite granitic dykes, and twomica granite. Scandium is enriched in Group III (50-154 ppm) relative to the other groups (26-58 ppm). Metal elements Sn (8-128 ppm) and Zn (204-1480) increase with decreasing $\mathrm{K} / \mathrm{Rb}$. The concentration of other metallic elements, such as $\mathrm{Cu}(1-60 \mathrm{ppm})$, Mo (<2 ppm), and $\mathrm{W}(<15 \mathrm{ppm})$ are independent of $\mathrm{K} / \mathrm{Rb}$ (Fig. 5, Table 2).

\section{Biotite halogen chemistry}

Most (70 to $90 \%$ ) of the F content of muscovite- and fluorite-free granitoid rocks is contained in biotite (Grabezkev et al., 1979), with the remainder being in apatite and titanite. The range of $\mathrm{F}$ contents of biotites from the Nashwaak Granites and related dykes is from 0.11 to $0.83 w t . \%$. In contrast, because ionic radius of $\mathrm{Cl}^{-}$is larger $(1.81 \AA)$ 
than that of $\mathrm{F}^{-}(1.31 \AA)$ or $\mathrm{OH}^{-}(1.38 \AA)(\mathrm{Munoz}, 1984)$, the amount of $\mathrm{Cl}$ substitution in the $\mathrm{OH}$ site is less than that of $\mathrm{F}$; it varies widely between 0.01 and $0.28 w t . \%$ in these biotites. The extent of halogen replacement of hydroxyl in biotite is governed by its $\mathrm{Mg} / \mathrm{Fe}$ ratio. Biotites with high $\mathrm{Mg} / \mathrm{Fe}$ ratios tend to incorporate more $\mathrm{F}$, and low $\mathrm{Mg} / \mathrm{Fe}$ biotites contain more $\mathrm{Cl}$, as noted by Munoz (1984). This correlation is caused by the crystal-chemical effect known as "F-Fe avoidance" and "Mg-Cl avoidance" (Munoz, 1984). In order to calculate relative degree of halogen enrichment in biotite, intercept values, $\operatorname{IV}(\mathrm{F}), \operatorname{IV}(\mathrm{Cl})$, and $\operatorname{IV}(\mathrm{F} / \mathrm{Cl})$, were developed by Munoz (1984) that have been corrected by the effect of $\mathrm{Mg} / \mathrm{Fe}$ ratios, and are given by the following equations

$$
\begin{aligned}
& \operatorname{IV}(\mathrm{F})=1.52 \mathrm{X}_{\mathrm{phl}}+0.42 \mathrm{X}_{\mathrm{ann}}+0.20 \mathrm{X}_{\mathrm{sid}}-\log \left(\mathrm{X}_{\mathrm{F}} / \mathrm{X}_{\mathrm{OH}}\right) \\
& \operatorname{IV}(\mathrm{Cl})=-5.01-1.93 \mathrm{X}_{\mathrm{phl}}-\log \left(\mathrm{X}_{\mathrm{Cl}} / \mathrm{X}_{\mathrm{OH}}\right) \\
& \operatorname{IV}(\mathrm{F} / \mathrm{Cl})=\operatorname{IV}(\mathrm{F})-\operatorname{IV}(\mathrm{Cl})
\end{aligned}
$$

Where $X_{\mathrm{phl}}=\mathrm{Mg} /$ sum of octahedral cations; $\mathrm{X}_{\mathrm{sid}}=[(3-\mathrm{Si} / \mathrm{Al}) / 1.75]\left(1-\mathrm{X}_{\mathrm{phl}}\right) ; \mathrm{X}_{\mathrm{ann}}=1$ $\left(\mathrm{X}_{\mathrm{phl}}+\mathrm{X}_{\mathrm{sid}}\right)$. The smaller intercept value representing higher degree of halogen enrichment in biotites.

The biotite from the two-mica granite (Group I) is distinct from the other groups by its low $\operatorname{IV}(\mathrm{F})(1.51$ to 2.16 , mean $=1.73)$ and high $\operatorname{IV}(\mathrm{Cl})(-3.56$ to -2.13 , mean $=-2.77)$. The IV $(\mathrm{F}), \operatorname{IV}(\mathrm{Cl})$, and $\mathrm{IV}(\mathrm{F} / \mathrm{Cl})$ of biotite from other groups of samples are between 1.76 and $2.64,-4.11$ and -2.03 , and 3.89 and 6.51 , respectively. The diagram of $\mathrm{IV}(\mathrm{F} / \mathrm{Cl})$ and $\mathrm{IV}(\mathrm{F})$ shows that they have a positive correlation (i.e., $\mathrm{IV}(\mathrm{F} / \mathrm{Cl})$ decreases with decreasing IV(F) (Fig. 6). Loferski and Ayuso (1995) explained that the decrease of IV(F) value might be caused by crystal fractionation processes during which $F$ concentrates in the late magmaic stage. The $\mathrm{F} / \mathrm{Cl}$ intercept values for biotites from 
porphyry copper deposits, Mo-W-Sn-Be deposits (excluding Henderson) and the Henderson porphyry molybdenum deposit were plotted against IV(F) by Munoz (1984). In the $\mathrm{IV}(\mathrm{F} / \mathrm{Cl})$ versus $\mathrm{IV}(\mathrm{F})$ diagram (Fig. 6), biotite from Group I has more $\mathrm{F}$ enrichment (low $\operatorname{IV}(\mathrm{F})$ ), which is similar to that of the Henderson porphyry Mo deposit. Biotite from Group II has wide range of $\mathrm{IV}(\mathrm{F} / \mathrm{Cl})$ varying from 4 to 6.5 . The overlap of the IV $(\mathrm{F} / \mathrm{Cl})$ ratio in biotite between Groups III and IV and those of the Sn-W-Be deposits indicates that the magma or fluids that were in equilibrium with those biotites had similar $f(\mathrm{HCl}) / f(\mathrm{HF})$ fugacity ratio (Table 1 , Appendix Table A).

\section{Halogen fugacity of associated fluids}

The contents of fluorine and chlorine in biotite may be used to calculate the halogen fugacity in associated magma or fluids (Munoz, 1984, 1992; van Middelaar and Keith, 1990; Loferski and Ayuso, 1995; Selby and Nesbitt, 1998, 2000; Yang and Lentz, 2005; Ayati et al, 2008; Boomeri et al., 2009, 2010). Calculations can be made in terms of the following equations proposed by Munoz (1992) based on the revised coefficients for FCl-OH partitioning between biotite and the hydrothermal fluid (Zhu and Sverjensky, 1991, 1992).

$\log \left(f \mathrm{H}_{2} \mathrm{O} / f \mathrm{HF}\right)^{\text {fluid }}=1000 / \mathrm{T}\left(2.37+1.1 \mathrm{X}_{\mathrm{phl}}\right)+0.43-\log \left(\mathrm{X}_{\mathrm{F}} / \mathrm{X}_{\mathrm{OH}}\right)^{\text {biotite }}$

$\log \left(f \mathrm{H}_{2} \mathrm{O} / f \mathrm{HCl}\right)^{\text {fluid }}=1000 / \mathrm{T}\left(1.15-0.55 \mathrm{X}_{\mathrm{phl}}\right)+0.68-\log \left(\mathrm{X}_{\mathrm{Cl}} / \mathrm{X}_{\mathrm{OH}}\right)^{\text {biotite }}$

$\log (f H F / f H C l)^{\text {fluid }}=-1000 / \mathrm{T}\left(1.22+1.65 \mathrm{X}_{\mathrm{phl}}\right)+0.25+\log \left(\mathrm{X}_{\mathrm{F}} / \mathrm{X}_{\mathrm{Cl}}\right)^{\text {biotite }}$

where $\mathrm{X}_{\mathrm{F}}, \mathrm{X}_{\mathrm{Cl}}$, and $\mathrm{X}_{\mathrm{OH}}$ are mole fractions of $\mathrm{F}, \mathrm{Cl}$, and $\mathrm{OH}$ in the hydroxyl site of biotite, respectively. $\mathrm{T}$ is the equilibrium temperature (in Kelvin) which could be estimated by the $\mathrm{X}_{\mathrm{phl}}$ and $\mathrm{X}_{\mathrm{PDoxy}}\left(\mathrm{Fe}^{3+} /\right.$ sum of octahedral ions) of hydrothermal biotites (Beane, 1974) or by the Ti content of biotite from graphitic-peraluminous-metapelites, 
which contain ilmenite or rutile (Henry et al., 2005). However, for biotite from igneous rocks, Yang and Lentz (2005) calculated oxygen fugacity of the associated magmas by using zircon-, apatite-, and (or) monazite-saturation temperatures (Watson and Harrison, 1983; Harrison and Watson, 1984; Montel, 1993). The zircon saturation temperatures of the Nashwaak Granites and related dykes are from 719 to $819{ }^{\circ} \mathrm{C}$ (Zhang, 2015). The calculated $\log \left(f \mathrm{H}_{2} \mathrm{O} / f \mathrm{HF}\right), \log \left(f \mathrm{H}_{2} \mathrm{O} / f \mathrm{HCl}\right)$, and $\log (f \mathrm{HF} / f \mathrm{HCl})$ ratios of magmatic fluids in equilibrium with magma (based on the equations mentioned above) are shown in Fig. 7. The fluids of Group I have $\log (f \mathrm{HF} / \mathrm{fHCl})$ ratio (mean $=0.22$ ) and lower $\log \left(f \mathrm{H}_{2} \mathrm{O} / \mathrm{fHCl}\right)($ mean $=4.15)$ than that of the other groups. The fluids associated with Group II have similar or slightly higher $\log \left(f \mathrm{H}_{2} \mathrm{O} / \mathrm{fHF}\right)($ mean $=4.34), \log \left(f \mathrm{H}_{2} \mathrm{O} / \mathrm{fHCl}\right)$ (mean $=4.16)$, and $\log (f \mathrm{HF} / f \mathrm{HCl})($ mean $=-0.18)$ than those fluids associated with Group III and IV. The fluids of Groups III and IV are relatively water-rich (more than 3 orders of magnitude relative to halogen fugacity) and $\mathrm{Cl}-$ rich $(\log (f \mathrm{HF} / \mathrm{fHCl})$ ratios are lower than 0), and are similar to the fluid composition associated with biotites from the porphyry-Cu deposits at Santa Rita, New Mexico, U.S.A (Munoz and Swenson, 1981). However, the fluids of Group I have more $\mathrm{F}$ than $\mathrm{Cl}(\log (\mathrm{fHF} / \mathrm{fHCl})$ ratios higher than 0$)$. Furthermore, the $\log \left(\mathrm{X}_{\mathrm{F}} / \mathrm{X}_{\mathrm{OH}}\right)$ vs. $\mathrm{X}_{\mathrm{Fe}}$ and $\log \left(\mathrm{X}_{\mathrm{Cl}} / \mathrm{X}_{\mathrm{OH}}\right)$ vs. $\mathrm{X}_{\mathrm{Mg}}$ plots of the biotites formed under the same $T, P$, and fluid composition would form linear trends (Zhu and Sverjensky, 1992). These linear trends are not observed for the biotite related to the Nashwaak Granites and dykes. The variation of halogen fugacity calculated by their zircon saturation temperature, and the scatter of the $\log \left(\mathrm{X}_{\mathrm{F}} / \mathrm{X}_{\mathrm{OH}}\right)$ vs. $\mathrm{X}_{\mathrm{Fe}}$ and $\log$ $\left(\mathrm{X}_{\mathrm{Cl}} / \mathrm{X}_{\mathrm{OH}}\right)$ vs. $\mathrm{X}_{\mathrm{Mg}}$ plots, could be explained by the possible continuous equilibration of biotites with fluids over a range of temperatures and of fluid composition. This is typical 
for magmatic fluids during cooling of granite plutons, manifested by $f \mathrm{HF} / f \mathrm{HCl}$ ratios of magmatic fluids that may progressively increase with differentiation (Yang and Lentz, 2005).

\section{Oxygen fugacity}

Oxygen fugacity $\left(\mathrm{fO}_{2}\right)$ exerts a control on the partitioning behaviour of Mo and $\mathrm{W}$ between ferromagnesian phases and melts, and on relative efficiencies of removal of these metals from the magmas into associated ore-forming fluids. Ore systems with high W/Mo ratios are relatively reduced, whereas systems with low W/Mo are oxidized (Candela and Bouton, 1990). Blevin and Chappell (1992) explained that during fractionation of magma, W and Mo are sequestered by Fe-Ti phases whose stability is normally $\mathrm{fO}_{2}$-dependent. Molybdenum is associated with oxidized felsic granites (Mengason et al., 2011), but $\mathrm{W}$ shows little dependence on magma redox conditions. However, besides the $\mathrm{Fe}^{3+} / \mathrm{Fe}^{2+}$ ratio of whole rocks, the $\mathrm{Fe}^{3+} / \mathrm{Fe}^{2+}$ ratio of biotite is also used to constrain oxygen fugacity of the associated magma system. Shabani et al. (2003) investigated the composition of biotites from the Gander zone of New Brunswick, which falls on or above nickel-nickel oxide (NNO) buffer in the $\mathrm{Fe}^{3+}-\mathrm{Fe}^{2+}-\mathrm{Mg}$ diagram of Wones and Eugster (1965). Wones and Eugster (1965) found biotite crystallizing from a magma that contains sanidine and magnetite may follow either an iron-rich trend or a magnesium-rich trend depending upon the $\mathrm{fO}_{2}$ conditions during crystallization over cooling. Thus, the total $\mathrm{Fe}$ and $\mathrm{Mg}$ ratio of biotite is another useful quantitative tool that can be used to estimate $\mathrm{fO}_{2}$ instead of $\mathrm{Fe}^{3+}$ and $\mathrm{Fe}^{2+}$, which cannot be measured directly by EMPA. In the $\mathrm{fO}_{2}$ vs. $T$ diagram (Fig. 8), biotites in Groups I and II samples are plotted along the quartz-fayalite-magnetite (QFM) buffer at high temperatures, and 
increase above the nickel-nickel oxide buffer with cooling of magmas. The increase of $\mathrm{fO}_{2}$ during magma evolution may attributed to $\mathrm{H}_{2}$ release at or near $\mathrm{H}_{2} \mathrm{O}$ vapour saturation at high $\mathrm{H}_{2} \mathrm{O} / \mathrm{Fe}^{2+}$ (cf. Candela, 1986a; Lentz, 1992). The biotite from the dykes (Groups III and IV) plot around the nickel-nickel oxide buffer, indicating that these dykes formed at relatively higher oxygen fugacity than that of plutonic phases (Groups I and II). The oxygen fugacity of all the samples is generally between $10^{-14}$ and $10^{-16}$ bars at between 719 and $819^{\circ} \mathrm{C}$ estimated from zircon saturation geothermometer (Watson and Harrison, 1983). In these samples, Group I and some of Group II have the the $\mathrm{fO}_{2}$ values comparable with that of strongly contaminated reduced I-type granites of Ague and Brimhall (1988a, b), whereas the $\mathrm{fO}_{2}$ of Group III are close to oxidized I-type granites (Ague and Brimhall, 1988a, b; Candela, 1989b).

On the other hand, magnetic susceptibility meter (KT-10) measurements ( $\mathrm{n}=3$ for each sample) yielded average values that lie along the boundary of the magnetite series and ilmenite series granites $\left(1 \times 10^{-4} \mathrm{emu} / \mathrm{g}\right.$; Ishihara, 1981). This result is in accordance with the findings of Shabani et al. (2003), who demonstrated that the magnetite/ilmenite ratio in granites varies considerably in the Gander Zone of New Brunswick.

\section{Discussion}

\subsection{Petrogenetic implications}

On the $\sum \mathrm{Al}-\mathrm{Mg}$ diagram of Nachit et al. (1985) and $\mathrm{MgO}-\sum \mathrm{FeO}-\mathrm{Al}_{2} \mathrm{O}_{3}$ diagram of Abdel-Rahman (1994), biotites from the Nashwaak Granites and related dykes are located in the peraluminous and calc-alkaline fields, likely formed in a subduction and/or collisional setting. This conclusion is supported by their whole rock geochemistry (Zhang, 2015) with low Nb, Rb, and Y contents indicating a volcanic arc setting (Pearce, 
1984). Also, this is consistent with the research of Whalen (1993) who plotted the composition of Siluro-Devonian granitic rocks from the Gander Zone in the diagrams of Pearce et al. (1984) and most of these granites straddle the boundary between volcanicarc to within-plate granites. In these granites, negative correlation between $\mathrm{Al}$ and $\mathrm{Mg}$ of biotite are controlled by different substitution mechanisms as shown by Abdel-Rahman (1994), Stussi and Cuney (1996) and Fleet (2003). Average Al content is lower in biotite in calc-alkaline granites than that in peraluminous granites because of lower activity of $\mathrm{Al}_{2} \mathrm{O}_{3}$ in calc-alkaline magmas.

Almost all the $\mathrm{F}$ present in the continental crust resides in granitoids and their metamorphic counterparts. Thus, $\mathrm{F}$ contents in granitoids may be related to the nature of magma source rock and the melting process involved. Whether $\mathrm{F}$ behaves as an incompatible or compatible element in magmas depends on whether the resultant magmatic rocks contain anhydrous or hydrous mineral assemblages (Sallet, 2000). Ague and Brimhall (1988a, b) studied regional variations in bulk chemistry and mineralogy in the batholiths of California. In those I-type granitoids, the $\mathrm{F} / \mathrm{OH}$ value of biotite increases with the degree of crustal contamination and the biotites in strongly reduced I-type granitoids are enriched in iron. However, Loferski and Ayuso (1995) investigated the biotite composition from some plutons in Maine that do not display a systematic regional variation. Comparing to the biotite composition of I-type granitoid rocks in the Sierra Nevada batholith of California (Ague and Brimhall, 1988a, b), biotites in the Nashwaak Ganites and related dykes are plotted along the border between oxidized and reduced Itype granites with weak to medium crustal contamination. The crustal contribution to the Nashwaak granites and related dykes as shown by the whole-rock $\delta^{18} \mathrm{O}(9.3-10.9 \%)$, 
$\varepsilon_{\mathrm{Nd}}(\mathrm{T})(-4.51$ to -1.42$)$, and the ${ }^{206} \mathrm{~Pb} /{ }^{204} \mathrm{~Pb},{ }^{207} \mathrm{~Pb} /{ }^{204} \mathrm{~Pb},{ }^{208} \mathrm{~Pb} /{ }^{204} \mathrm{~Pb}$ values of $18.3,15.6$, and 38.3, respectively (Ayuso and Bevier, 1991; Zhang, 2015), implys that these Nashwaak granitoids originated from infracrustal sources (Bevier and Whalen, 1990; Whalen, 1993). Whalen et al. (1996) interpreted those granitic magmas to be derived from bulk assimilation of Mesoproterozoic Gondwanan basement \pm the overlying Gander Zone sedimentary prism, by enriched asthenospheric mantle-derived melts. In Fig. 9, the value of $\log \left(\mathrm{X}_{\mathrm{Mg}} / \mathrm{X}_{\mathrm{Fe}}\right)=-0.21$ was chosen as the dividing line between the reduced and oxidized rocks because of absence of muscovite, garnet, and tourmaline and the presence of titanite at higher values of $\log \left(\mathrm{X}_{\mathrm{Mg}} / \mathrm{X}_{\mathrm{Fe}}\right)$ in the batholiths of California (Ague and Brimhall, 1988a,b). However, the experiment of Wones and Eugster (1965) indicated that the biotite with a constant $\mathrm{Fe} / \mathrm{Mg}$ ratio represents more oxidized setting if it crystallized at lower temperatures (i.e. from $\mathrm{CO}_{2}-\mathrm{CH}_{4}$ buffer at $900{ }^{\circ} \mathrm{C}$ to $\mathrm{Ni}-\mathrm{NiO}$ buffer at $700{ }^{\circ} \mathrm{C}$ ). Ague and Brimhall (1988b) calculated oxygen fugacity based on the representative conditions of $800{ }^{\circ} \mathrm{C}$ for the batholiths of California and the $\log \left(\mathrm{X}_{\mathrm{Mg}} / \mathrm{X}_{\mathrm{Fe}}\right)$ of -0.21 was chosen to divide the oxidized and reduced granites. The Nashwaak Granites and related dykes crystallized at temperatures lower than $800{ }^{\circ} \mathrm{C}$ (Zhang, 2015). Thus the line of log $\left(\mathrm{X}_{\mathrm{Mg}} / \mathrm{X}_{\mathrm{Fe}}\right)$ between oxidized and reduced granites should be lower than -0.21 (Fig. 9) for the Nashwaak Granites and related dykes and some of the points in the I-SCR area might represent the oxidized I-type granites (Fig. 9).

\subsection{Metallogenic implication of volatiles}

\subsubsection{Water content in melts}

Water vapor is a major volatile component in natural aluminosilicate melts, and controls the chemical and physical properties of magmas, such as phase relationships, 
viscosity, density and diffusivity (Holtz et al., 2001). In ore deposit related melts, water content influences hydrothermal evolution behaviour as shown by the model of Burnham (1979) and William-Jones and Heinrich (2005). This is because water promotes the segregation of metal elements from the melt to ore fluids (Candela, 1989a). The water content in granitic melts could be estimated using the method developed by Holtz et al. (2001) if the initial temperature and pressure are known. However, temperature estimation by using zircon saturation thermometer (Watson and Harrison, 1983) indicates that the Nashwaak Granites and related dykes are 'cold' granites $\left(\mathrm{T}_{\mathrm{Zr}}<800{ }^{\circ} \mathrm{C}\right.$, Zhang, 2015) as defined by Miller et al. (2003). The presence of inherited zircons in these magmas shows that zircon is saturated and thus $\mathrm{T}_{\mathrm{Zr}}$ could represent the initial magma temperature at the source (Miller et al., 2003). At moderate crustal depths (equivalent to lithostatic pressures of $4-8 \mathrm{~kb}$ ), the melts forming the Nashwaak Granites and dykes contain $\sim 4-5 \%$ water in the $P-T-\mathrm{H}_{2} \mathrm{O}$ diagram of Holtz et al. (2001). This estimated water content is significantly higher than that of magmas resulted in scheelite skarn granitoids ranging from $2 \%$ to $4 \%$ as suggested by Newberry and Swanson (1986). Candela $(1989 \mathrm{a}, \mathrm{b})$ suggested that the ratio of the initial water concentration to the saturation water concentration in the melt is the important parameter when calculating the proportion of any given ore metal removed from the magma into an ore fluid. Tungsten (Mo) deposits usually have lower ratios than that of porphyry $\mathrm{Cu}$ deposits, since $\mathrm{W}$ (Mo) behaves as incompatible elements and their enrichment needs a significant amount of crystallization before water content is increased to the saturation level. This could explain why large W skarn deposits are related to deep emplacement of $\mathrm{H}_{2} \mathrm{O}$-poor magmas (Newberry and Swanson, 1986; Keith et al., 1989; van Middelaar and Keith, 1990; 
Newberry, 1998; Rasmussen et al., 2011). In the $\mathrm{H}_{2} \mathrm{O}$-poor system, $\mathrm{HF}$ has essentially the same effect per unit mass as $\mathrm{H}_{2} \mathrm{O}$ on melting relations according to the model of Burnham (1979), this suggests that magmas produced by partial melting of a source region with a high $\mathrm{F} / \mathrm{H}_{2} \mathrm{O}$ ratio will be impoverished in water, and will therefore experience a protracted crystallization history before vapour evolution, allowing $\mathrm{W}$, Mo, and other incompatible elements to concentrate in the melt (e.g., Climax-type Mo deposits) relative to compatible elements such as copper (Candela 1989b). For the Nashwaak Granites and related dykes, the water cannot be derived from dehydration melting of biotite and/or hornblende since the temperature is too low $\left(\mathrm{T}_{\mathrm{Zr}}<800{ }^{\circ} \mathrm{C}\right)$ (Patino Douce and Harris, 1998) and therefore, fluid influx would be required.

\subsubsection{Implication of halogen elements}

Experiments of $\mathrm{W}$ and Mo partitioning behaviour between melt and fluid show that the majority of dissolved tungsten species in hydrothermal solutions occur as tungstates and have the forms $\mathrm{H}_{2} \mathrm{WO}_{4}, \mathrm{HWO}_{4}^{-}$, and $\mathrm{WO}_{4}^{-2}$ (Candela and Holland, 1984; Keppler and Wyllie, 1991; Wood and Samson, 1998, 2000;). Molybdenum tends to be more easily reduced in nature than tungsten. Besides the similar species of $\mathrm{H}_{2} \mathrm{MoO}_{4}, \mathrm{HMoO}_{4}$, and $\mathrm{MoO}_{4}^{-2}$ as tungsten in the fluids, the $\mathrm{MoO}^{2+}$ and $\mathrm{Mo}(\mathrm{OH})^{3+}$ also possibly formed under reducing conditions (Wood and Samson, 1998; Rempel et al., 2009). Molybdenum oxychloride complexes (i.e., $\mathrm{MoO}_{2} \mathrm{Cl}^{+}$) might only be present at very acid conditions (Bernard et al., 1990; Yokoi et al., 1993). Results of some experiments indicate that tungsten or molybdenum -chloride or -fluoride is not necessarily required to transporting significant W and Mo to form an ore deposit (Candela and Holland, 1984; Eugster, 1985; 
Wood and Vlassopoulos, 1989; Keppler and Wyllie, 1991; Gilbert et al., 1992; Wood, 1992; Wood and Samson, 1998, 2000).

Although W and Mo transported in the hydrothermal fluids is not directly combined with halogen elements, the ratio of $\mathrm{F}, \mathrm{Cl}$, and $\mathrm{H}_{2} \mathrm{O}$ in the magma system are still worthwhile to be discussed since they could be the W (Mo) mineralization vectors (Candela, 1989b; Rasmussen and Mortensen, 2013). However, the halogen composition of magma is dictated by the composition of source rock and the differentiation degree of magma (Keith et al., 1989; van Middelaar and Keith, 1990; Loferski and Ayuso, 1995; Christiansen and Keith, 1996; Sallet, 2000). The I-type magmas of the Nashwaak Granites and related dykes were derived from partial melting of lower crust, which could be the seismically defined Central Crustal Block that underlies the area (Keen et al., 1986; Marillier et al., 1989; Quinlan et al., 1992; Zhang, 2015). Partial melting of a dehydrated protolith (consisting of granulite-grade metamorphic rocks) would be rather rich in F occurring in the remaining hydrous minerals (Holloway, 1977; Burt, 1982; Ague and Brimhall, 1988a, b; Loferski and Ayuso, 1995). As the magmatic system evolves, chlorine is strongly partitioned into fluids over melt when the volatile phase exsolves, whereas the fluorine displays the opposite behaviour partitioning into minerals in the melt (Coulson et al., 2001; Rasmussen and Mortensen, 2013). Thus, the $\mathrm{Cl} / \mathrm{F}$ and $\mathrm{H}_{2} \mathrm{O} / \mathrm{F}$ decrease with magma differentiation accompanied by volatile release from the magma system (Candela, 1986b; Keith et al., 1989; van Middelaar and Keith, 1990; Loferski and Ayuso, 1995; Christiansen and Keith, 1996; Webster, 1997a, b). Anomalously high $\mathrm{HCl} / \mathrm{HF}$ and $\mathrm{H}_{2} \mathrm{O} / \mathrm{HF}$ ratios of biotites from highly differentiated granites might represent a build-up of volatiles $\left(\mathrm{Cl}, \mathrm{H}_{2} \mathrm{O}\right)$ as well as $\mathrm{W}$ and $\mathrm{Mo}$ within a magmatic system, and 
thus could be tungsten mineralization vectors (Rasmussen and Mortensen, 2013). However, the Nashwaak Granites and related dykes are all highly evolved granites and anomalous halogen activity ratios as those observed in Rudi and Lened pluton (Rasmussen and Mortensen, 2013) were not found. Except for the two-mica granite which has high $\mathrm{F} / \mathrm{Cl}$ due to crustal contamination as discussed before, the other groups of rocks have the $\log \left(f \mathrm{HCl} / \mathrm{HF}\right.$ ) larger than 0.0 , and the $\log \left(f \mathrm{H}_{2} \mathrm{O} / \mathrm{HF}\right.$ ) larger than 4.0 (cf. Fig. 7). The lack of extremely high $\mathrm{Cl} / \mathrm{F}$ and $\mathrm{H}_{2} \mathrm{O} / \mathrm{F}$ ratios in the Nashwaak Granites and related dykes may indicates that a large granitic pluton as a source for mineralizing hydrothermal fluids at Sisson Brook deposits is not exposed (Rennie, 2012). Alternatively, the halogen ratios of biotites may not be able to effectively distinguish mineralized systems from barren systems (Munoz, 1984) and the granites associated with tungsten deposits have no restricted ranges of $\mathrm{F} / \mathrm{Cl}$ ratios (Keith et al., 1989; van Middelaar and Keith, 1990).

\section{Conclusions}

The Sisson Brook W-Mo-Cu deposit formed, in part, by magmatic hydrothermal fluids inferred to be related to one of the four phases of the Nashwaak Granites and related dykes. Analysis results on primary magmatic biotites helped to investigate magmatic evolution processes and evaluate composition of related fluids. The compositions of biotites within the Nashwaak Granite and associated dykes indicate that their magmas were emplaced in a subduction and/or collisional setting. According to the classification of I-type granitoids of Ague and Brimhall (1988a, b), the biotite granite pluton (Group II) and dykes (Group III and IV) are similar to the weakly to moderately 
contaminated I-type granite, whereas the muscovite-biotite granite (Group I) is similar to the strongly contaminated and reduced I-type granites.

The $\mathrm{K} / \mathrm{Rb}$ ratio of biotite decreases with magma fractionation. The same trend is observed for compatible elements (in felsic rocks) $\mathrm{Cr}$, $\mathrm{Ti}, \mathrm{Co}, \mathrm{V}$, and $\mathrm{Ba}$ in Groups II, III, and IV, but Group I is slightly off this trend. The incompatible elements Ta, Tl, Ga, Cs, $\mathrm{Li}$, and $\mathrm{Sn}$ show a reverse distribution pattern. Interestingly, $\mathrm{Ni}$ is scattered in those groups. Partitioning of $\mathrm{W}$ and $\mathrm{Cu}$ into biotite is not (or not entirely) controlled by magma fractionation (cf. Fig. 5) as no obvious correlation is evident. Molybdenum in these magmas is lower than $2 \mathrm{ppm}$.

Compared to $\mathrm{Cl}$-rich magma systems related to porphyry $\mathrm{Cu}$ deposits, porphyry $\mathrm{Mo}$ deposits are more enriched in $\mathrm{F}$. The high $\mathrm{F} / \mathrm{Cl}$ ratio of magma in porphyry Mo systems could be inherited from their metamorphic source rocks or could be due to vapour exsolution during magma evolution that may have leached the $\mathrm{Cl}$ out of the system. The calculated halogen fugacity of magmas associated with the Nashwaak Granites and related dykes shows that Group I has undergone some degree of crustal contamination and thus has higher $\mathrm{F} / \mathrm{Cl}$ than the other groups, and similar to those magmas associated with the Henderson porphyry Mo deposit. Groups II, III, and IV have their $\log (f \mathrm{HF} / \mathrm{HCl})$ broadly lower than 0.0 , and their $\log \left(\mathrm{fH}_{2} \mathrm{O} / \mathrm{HF}\right)$ larger than 4.0. Anomalously high $\mathrm{Cl} / \mathrm{F}$ and $\mathrm{H}_{2} \mathrm{O} / \mathrm{F}$ ratios which could be the $\mathrm{W}$ and Mo mineralization vectors (Rasmussen and Mortensen, 2013) were not found in the Nashwaak Granites and related dykes

The Mo-W enrichment and mineralization are likely to form from slightly oxidized magmas (Blevin and Champell, 1992), since Mo is more easily sequestered from the magma system in reduced settings Tungsten shows little dependence on redox conditions 
of a magma although high grade $\mathrm{W}$ deposits are usually related to the reduced granites (Mahood and Hildreth, 1983; Candela and Bouton, 1990; Blevin and Chappell, 1992). In the Nashwaak Granites and related dykes, the dyke phases (Groups III and IV) have the oxygen fugacity around the nickel-nickel oxide buffers. The plutonic phases (Groups I and II) have the oxygen fugacity around the quartz-fayalite-magnetite (QFM) buffer at high temperatures and oxidized to nickel-nickel oxide buffer at lower temperatures. The oxidation process in the plutonic phases (Groups I and II) could be caused by $\mathrm{H}_{2}$ release at or near $\mathrm{H}_{2} \mathrm{O}$ vapour saturation at high $\mathrm{H}_{2} \mathrm{O} / \mathrm{Fe}^{2+}$ (cf. Candela, 1986a; Lentz, 1992). Although several other vital factors could control W and Mo mineralization, such as the ratio of initial water content to saturation water content in the magma, emplacement depth, the difference of those factors between each group is difficult to precisely determine. If only considering the evolution degree of magma and oxygen fugacity interpreted from the composition of biotite, the magmatic source of the biotite granitic dykes (Group III) is the plausible source of the hydrothermal fluids responsible for the Sisson Brook deposit mineralization since it has the highest differentiation degree and formed in an oxidized setting.

\section{Acknowledgements}

This research was funded by the New Brunswick Department of Energy and Mines, Geodex Minerals Ltd., and a NSERC Discovery grant to Dave Lentz. Support by Charlie Morrissy and Justin Bernard during field work was greatly appreciated. Thanks to Geodex Minerals Ltd. for allowing access to their property and information. This manuscript benefitted from constructive discussions with Thierry Bineli-Betsi, Ayalew 
Gebru, Dongyang Zhang, and Bo Xiao and a preliminary review by Dr. Steve McCutcheon.

\section{References}

Abdel-Rahman, A.F.M., 1994. Nature of biotites from alkaline, calc-alkaline, and peraluminous magmas. J. Petrol. 35, 525-541.

Abdel-Rahman, A.F.M., 1996. Discussion on the comment on nature of biotites in alkaline, calc-alkaline and peraluminous magmas. J. Petrol. 37, 1031-1035.

Ague, J.J., Brimhall, G.H., 1988a. Regional variations in bulk chemistry, mineralogy, and the compositions of mafic and accessory minerals in the batholiths of California. Geol. Soc. Am. Bull. 100, 891-911.

Ague, J.J., Brimhall, G.H., 1988b. Magmatic arc asymmetry and distribution of anomalous plutonic belts in the batholiths of California: Effects of assimilation, crustal thickness, and depth of crystallization. Geol. Soc. Am. Bull. 100, 912-927.

Ayati, F., Yavus, F., Noghreyan, M., Haroni, H.A., Yavuz, R., 2008. Chemical characteristics and composition of hydrothermal biotite from the Dalli porphyry copper prospect, Arak, central province of Iran. Mineral. Petrol. 94, 107-122.

Ayuso, R.A., Bevier, M.L., 1991. Regional differences in lead isotopic compositions of feldspars from plutonic rocks of the northern Appalachian mountains, U.S.A. and Canada: a geochemical method of terrane correlation. Tectonics 10, 191-212.

Beane, R.E., 1974. Biotite stability in the porphyry copper environment. Econ. Geol. 69, 241-256.

Bernard, A., Symonds, R.B., JR Rose, W.I., 1990. Volatile transport and deposition of Mo, W and Re in high temperature magmatic fluids. Appl. Geochem. 5, 317-326. 
Bevier, M.L., Whalen, J.B., 1990. Tectonic significance of Silurian magmatism in the Canadian Appalachians. Geology 18, 411-414.

Blevin, P.L., Chappell, B.W., 1992. The role of magma sources, oxidation states and fractionation in determining the granite metallogeny of eastern Australia. Trans. Roy. Soc. Edinb. Earth Sci. 83, 305-316.

Boomeri, M., Nakashima, K., Lentz, D.R., 2009. The Miduk porphyry $\mathrm{Cu}$ deposit, Kerman, Iran: A geochemical analysis of the potassic zone including halogen element systematics related to $\mathrm{Cu}$ mineralization processes. J. Geochem. Explor. $103,17-29$.

Boomeri, M., Nakashima, K., Lentz, D.R., 2010. The Sarcheshmeh porphyry copper deposit, Kerman, Iran: A mineralogical analysis of the igneous rocks and alteration zones including halogen element systematics related to $\mathrm{Cu}$ mineralization processes. Ore Geol. Rev. 38, 367-381.

Brimhall, G.H., Crerar, D.A., 1987. Ore fluids: Magmatic to supergene. In: Carmichael, I.S.E., Eugster, H.P. (Ed.), Thermodynamic Modeling of Geological Materials: Minerals, Fluids and Melts. Rev. Mineral. 17, pp. 235-322.

Burnham, C.W., 1979. Magmas and hydrothermal fluids. In: Barnes, L.H. (Ed.), Geochemistry of Hydrothermal Ore Deposits, $2^{\text {nd }}$ edition. John Wiley \& Sons, New York, pp. 71-136.

Burt, D.M., Bikun, J.V., Christiansen, E.H., 1982. Topaz rhyolites-distribution, origin, and significance for exploration. Econ. Geol. 77, 1818-1836.

Bustard, A., 2013. Tungsten mineralization processes at the Sisson Brook W-Mo-Cu deposit, central New Brunswick: the role of formation of titaniferous phases at 
reaction fronts. B.Sc thesis, unpublished.

Candela, P.A., 1986a. The evolution of aqueous vapour from silicate melts: effect of oxygen fugacity. Geochim. Cosmochim. Acta 50, 1205-1211.

Candela, P.A., 1986b. Toward a thermodynamic model for the halogens in magmatic systems: an application to melt-vapor-apatite equilibria. Chem. Geol. 57, 289-301.

Candela, P.A., 1989a. Magmatic ore-forming fluids: Thermodynamic and mass transfer calculations of metal concentrations. In: Whitney, J.A., Naldrett, A.J. (Ed.), Ore Deposition Associated with Magmas. Rev. Econ. Geol. 4, pp. 203-220.

Candela, P.A., 1989b. Felsic magmas, volatiles, and metallogenesis. In: Whitney, J.A., Naldrett, A.J. (Ed.), Ore Deposition Associated with Magmas. Rev. Econ. Geol. 4, pp. 223-233.

Candela, P.A., Bouton, S.L., 1990. The influence of oxygen fugacity on tungsten and molybdenum partitioning between silicate melts and ilmenite. Econ. Geol. 85, 633640.

Candela, P.A., Holland, H.D., 1984. The partitioning of copper and molybdenum between silicate melts and aqueous fluids. Geochim. Cosmochim. Acta 48, 373-380.

Christiansen, E.H., Keith, J.D., 1996. Trace element systematics in silicic magmas: A metallogenic perspective. In: Wyman, D.A. (Ed.), Trace Element Geochemistry of Volcanic Rocks: Applications for Massive Sulphide Exploration. Geological Association of Canada, Short Course Notes 12, 115-151.

Coulson, I.M., Dipple, G.M., Raudsepp, M., 2001. Evolution of HF and $\mathrm{HCl}$ activity in magmatic volatiles of the gold-mineralized Emerald Lake pluton, Yukon, Territory, Canada. Miner. Deposita 36, 594-606. 
Eugster, H.P., 1985. Granites and hydrothermal ore deposits: A geochemical framework. Mineral. Mag. 49, 7-23.

Fleet, M.E., 2003. Rock-Forming minerals, 2nd edition. Volume 3A: Micas. The Geological Society of London, pp. 325-585.

Fyffe, L.R., Thorne, K.G., Dunning, G.R., Martin, D.A., 2008. U-Pb geochronology of the Sisson Brook granite porphyry, York County, West-central New Brunswick. In: Martin, G.L. (Ed.), Geological Investigations in New Brunswick for 2007. New Brunswick Department of Natural Resources, Minerals, Policy and Planning Division, Mineral Resource Report 2008-1, pp. 35-54.

Gilbert, F., Moine, B., Schott, J., Dandurand, J,L., 1992. Modeling of the transport and deposition of tungsten in the scheelite-bearing calc-silicate gneisses of the Montagne Noire, France. Contrib. Mineral. Petrol. 112, 371-384.

Gordiyenko, V.V., 1975. Geochemistry of the processes of pegmatite formation and muscovite generation. In Muscovite Pegmatites of the U.S.S.R., Nauka, Leningrad, 107-117 (in Russian).

Grabezkev, A.I., Vigorova, V.G., Chashukhina, V.A., 1979. Behavior of fluorine during crystallization of granites (in connection with validation of the criteria of granite specialization). Geochem. Int. 16, 23-33.

Harrison, T.M., Watson, E.B., 1984. The behavior of apatite during crustal anatexis: equilibrium and kinetic considerations. Geochim. Cosmochim. Acta 48, 1467-1477.

Henry, D.J., Guidotti, C.V., Thomson, J.A., 2005. The Ti-saturation surface for low-tomedium pressure metapelitic biotites: Implications for geothermometry and Tisubstitution mechanisms. Am. Mineral. 90, 316-328. 
Holloway, J.R., 1977. The effect of fluorine on dehydration equilibria. Geol. Soc. Am., Abstracts with Programs 9, 1021.

Holtz, F., Johannes, W., Tamic, N., Behrens, H., 2001. Maximum and minimum water contents of granitic melts generated in the crust: A re-evaluation and implications. Lithos 56, 1-14.

Idrus, A., Kolb, J., Meyer, F.M., 2007. Chemical composition of rock-forming minerals in copper-gold-bearing tonalite porphyries at the Batu Hijau deposit, Sumbawa Island, Indonesia: Implications for crystallization conditions and fluorine-chlorine fugacity. Resour. Geol. 57, 102-113.

Inverno, C.M.C., Hutchinson, R.W., 2006. Petrochemical discrimination of evolved granitic intrusions associated with Mount Pleasant deposits, New Brunswick, Canada. Applied Earth Science (Trans. Inst. Min. Metall. B) 115, 23-39.

Ishihara, S., 1981. The granitoid series and mineralization. In: Skinner, B.J. (Ed.), Economic Geology, $75^{\text {th }}$ anniversary volume: New Haven, Connecticut, Economic Geology Publishing Co., pp. 458-484.

Keen, C.E., Keen, M.J., Nichols, B., Reid, I., Stockmal, G.S., Colman-Sadd, S.P., O’Brien, S.J., Miller, H., Quinlan, G., Williams, H., Wright, J., 1986. Deep seismic reflection profile across the northern Appalachians. Geology 14, 141-145.

Keith, J.D., van Middelaar, W., Clark, A.H., Hodgson, C.J., 1989. Granitoid textures, compositions, and volatile fugacities associated with the formation of tungstendominated skarn deposits. In: Whitney, J.A., Naldrett, A.J. (Ed.), Ore deposition associated with magmas. Rev. Econ. Geol. 4, 235-250.

Keppler, H., Wyllie, P.J., 1991. Partitioning of Cu, Sn, Mo, W, U, and Th between melt 
and aqueous fluid in the systems haplogranite- $\mathrm{H}_{2} \mathrm{O}-\mathrm{HCl}$ and haplogranite- $\mathrm{H}_{2} \mathrm{O}-\mathrm{HF}$. Contrib. Mineral. Petrol. 109, 139-150.

Kooiman, G.J.A., McLeod, M.J., Sinclair, W.D., 1986. Porphyry tungsten-molybdenum orebodies, polymetallic veins and replacement bodies, and tin-bearing greisen zones in the Fire Tower Zone, Mount Pleasant, New Brunswick. Econ. Geol. 81, 13561373.

Lentz, D.R., 1992. Petrogenesis and geochemical composition of biotites in rare-element granitic pegmatites in the Southwestern Grenville Province, Canada. Mineral. Petrol. $46,239-256$.

Loferski, P.J., Ayuso, R.A., 1995. Petrography and mineral chemistry of the composite Deboullie pluton, northern Maine, U.S.A.: Implications for the genesis of $\mathrm{Cu}-\mathrm{Mo}$ mineralization. Chem. Geol. 123, 89-105.

Lofgren, G.E., 1974. Temperature induced zoning in synthetic plagioclase. In: MacKenzie, W.S., Zussman, J. (Ed.), The Feldspar. Manchester: Manchester University Press, pp. 362-375.

Lofgren, G.E., 1980. Experimental studies on the dynamic cystallization of silicate melts. In: Hargraves, R.B. (Ed.), Physics of Magmatic Processes. Princeton: Princeton University Press, pp. 487-551.

Lutes, G., 1981. Geology of Deersdale-Head of Nashwaak River map area J-17 and Upper parts of Nashwaak River-McBean and Sister Brooks, map area J-18. New Brunswick Department of Natural Resources; Mineral Resources, Map Report 81- 4, $1-26$. 
MacLellan, H.E., Taylor, R.P., 1989. Geology and geochemistry of the Burnthill Granite and related W-Sn-Mo-F mineral deposits, central New Brunswick. Can. J. Earth Sci. $26,499-514$.

Mahood, G.A., Hildreth, W., 1983. Large partition coefficient for trace elements in high silica rhrolites. Geochimica et Cosmochimica Acta 47, 11-30.

Mann, R., 1980. Report on diamond drilling at Sisson Brook. Unpublished company report, Kidd Creek Mines Ltd., Fredericton, New Brunswick, 1-36.

Marillier, F., Keen, C.E., Stockmal, G.S., Quinlan, G., Williams.H., Colman-Sadd, S.P., O'Brien, S.J., 1989. Crustal structure and sureface zonation of the Canadian Appalachians: implications of deep seismic reflection data. Can. J. Earth Sci. 26, 305-321.

McLeod, M.J., Johnson, S.C., Krogh, T.E., 2003. Archived U-Pb (zircon) dates from southern New Brunswick. Atl. Geol. 39, 209-225.

Mengason, M.J., Candela, P.A., Piccoli, P.M., 2011. Molybdenum, tungsten and manganese partitioning in the system pyrrhotite-Fe-S-O melt-rhyolite melt: Impact of sulfide segregation on arc magma evolution. Geochim. Cosmochim. Acta 75, 7018-7030.

Miller, C.F., McDowell, S.M., Mapes, R.W., 2003. Hot and cold granites? Implications of zircon saturation temperatures and preservation of inheritance. Geology 31, 529532.

Montel, J.M., 1993. A model for monazite/melt equilibrium and application to the generation of granitic magmas. Chem. Geol. 110, 127-146.

Munoz, J.L., 1984. F-OH and $\mathrm{Cl}-\mathrm{OH}$ exchange in micas with applications to 
hydrothermal ore deposits. Rev. Mineral. Geochem. 13, 469-493.

Munoz, J.L., 1992. Calculation of $\mathrm{HF}$ and $\mathrm{HCl}$ fugacities from biotite compositions: revised equations. Geol. Soc. Am., Abstracts with Programs 24, 221.

Munoz, J.L., Swenson, A., 1981. Chloride-hydroxyl exchange in biotite and estimation of relative $\mathrm{HCl} / \mathrm{HF}$ activities in hydrothermal fluids. Econ. Geol. 76, 2212-2221.

Nachit, H., Ibhi, A., Abia, E.H., Ohoud, M.B., 2005. Discrimination between primary magmatic biotites, reequilibrated biotites and neoformed biotites. C. R. Geosci. 337, 1415-1420.

Nachit, H., Razafimahefa, N., Stussi, J.M., Caron, J.P., 1985. Composition chimique des biotites et typologie magmatique des granitoïdes. C. R. Hebd. Acad. Sci. 301, 813818.

Nast, H.J., 1985. The geology and petrochemistry of the Sisson Brook W-Cu-Mo deposit, New Brunswick. (M.Sc. thesis) McGill University, Montreal, Quebec, 192 P.

Nast, H.J., Williams-Jones, A.E., 1991. The role of water-rock interaction and fluid evolution in forming the porphyry-related Sisson Brook W-Cu-Mo deposit, New Brunswick. Econ. Geol. 86, 302-317.

Newberry, R.J., 1998. W- and Sn-skarn deposits: A 1998 status report. In: Lentz, D.R. (Ed.), Mineralized Intrusion-related Skarn systems. Mineralogical Association of Canada Short Course Series 26, 289-336.

Newberry, R.J., Swanson, S.E., 1986. Scheelite skarn granitoids: An evalution of the roles of magmatic source and process. Ore Geol. Rev. 1, 57-81. 
Patiño Douce, A.E., 1993. Titanium substitution in biotite: an empirical model with applications to thermometry, $\mathrm{O}_{2}$ and $\mathrm{H}_{2} \mathrm{O}$ barometries, and consequences for biotite stability. Chem. Geol. 108, 133-162.

Patiño Douce, A.E., Harris, N., 1998. Experimental constraints on Himalayan anatexis. J. Petrol. 39, 689-710.

Pearce, J.A., Harris, N.B.W., Tindle, A.G., 1984. Trace element discrimination diagrams for the tectonic interpretation of granitic rocks. J. Petrol. 25, 956-983.

Quinlan, G.M., Hall, J., Williams, H., Wright, J.A., Colman-Sadd, S.P., O’Brien, S.J., Stockmal, G.S., Marillier, F., 1992. Lithoprobe onshore seismic reflection transects across the Newfoundland Appalachians. Can. J. Earth Sci. 29, 1865-1877.

Rasmussen, K.L., Lentz, D.R., Falck, H., 2011. Felsic magmatic phases and the role of late-stage aplitic dykes in the formation of the world-class Cantung Tungsten skarn deposit, Northwest Territories, Canada. Ore Geol. Rev. 41, 75-111.

Rasmussen, K.L., Mortensen, J.K., 2013. Magmatic petrogenesis and the evolution of $(\mathrm{F}: \mathrm{Cl}: \mathrm{OH})$ fluid composition in barren and tungsten skarn-associated plutons using apatite and biotite compositions: Case studies from the northern Canadian Cordillera. Ore Geol. Rev. 50, 118-142.

Rempel, K.U., Williams-Jones, A.E., Migdisov, A.A., 2009. The partitioning of molybdenum (VI) between aqueous liquid and vapour at temperatures up to $370{ }^{\circ} \mathrm{C}$. Geochim. Cosmochim. Acta 73, 3381-3392.

Rennie, D.W., 2012. Technical report on the Sisson Project, New Brunswick, Canada. Roscoe Postle Associates INC., 40-66. 
Rieder, M., Cavazzini, G., D’Yakonov, Y.S., Frank-Kamenetskii, V.A., Gottardi, G., Guoggenheim, S., Koval, P.V., Muller, G., Neiva, A.M.R., Radoslovich, E.W., Robert, J,L., Sssi, F.P., Takeda, H., Weiss, Z., Wones, D.R., 1998. Nomenclature of the micas. Can. Mineral. 36, 41-48.

Sallet, R., 2000. Fluorine as a tool in the petrogenesis of quartz-bearing magmatic associations: applications of an improved F-OH biotite-apatite thermometer grid. Lithos 50, 241-253.

Saravanan, C.S., Mishra, B., Jairam, M.S., 2009. P-T conditions of mineralization in the Jonnagiri granitoid-hosted gold deposit eastern Dharwar Craton, south India: Constraints from fluid inclusions and chlorite thermometry. Ore Geol. Rev. 36, 333349.

Selby, D., Nesbitt, B.E., 1997. Biotite Chemistry of the Casino Porphyry Cu-Mo-Au Occurrence, Dawson Range, Yukon. In: Yukon Exploration and Geology 1997; Exploration and Geological Services Division, Yukon, Indian and Northern Affairs Canada, 83-88.

Selby, D., Nesbitt, B.E., 2000. Chemical composition of biotite from the Casino porphyry $\mathrm{Cu}-\mathrm{Au}-\mathrm{Mo}$ mineralization, Yukon, Canada: evaluation of magmatic and hydrothermal fluid chemistry. Chem. Geol. 171, 77-93.

Shabani, A.A.T., Lalonde, A.E., Whalen, J.B., 2003. Composition of biotite from granitic rocks of the Canadian Appalachian Orogen: A potential tectonomagmatic indicator? Can. Mineral. 41, 1381-1396.

Siahcheshm, K., Calagari, A.A., Abedini, A., Lentz, D.R., 2012. Halogen signatures of biotites from the Maher-Abad porphyry copper deposit, Iran: characterization of 
volatiles in syn- to post-magmatic hydrothermal fluids. Inter. Geol. Rev. 54, 13531368.

Smith, E.A., Fyffe, L.R., 2006a. Bedrock geology of the Coldstream area (NTS 21 J/06). York and Carleton counties. New Brunswick. New Brunswick Department of Natural Resources. Minerals, Policy and Planning Division. Plate 2006-7.

Smith, E.A., Fyffe, L.R., 2006b. Bedrock geology of the Napadogan area (NTS 21 J/07). York and Carleton counties. New Brunswick. New Brunswick Department of Natural Resources. Minerals, Policy and Planning Division. Plate 2006-8.

Spear, J.A., 1984. Micas in igneous rocks. Rev. Mineral. 13, 299-356.

Stussi, J.M., Cuney, M., 1996. Nature of biotites from alkaline, calc-alkaline and peraluminous magmas by Abdel-Fattah M. Abdel-Rahman: A comment. J. Petrol. 37, 1025-1029.

Thorne, K.G., Fyffe, L.R., Creaser, R.A., 2013. Re-Os geochronological constraints on the W-Mo mineralizing event in the Mount Pleasant Caldera Complex: implications for the timing of subvolcanic magmatism and caldera development. Atl. Geol. 49, $131-150$.

Tischendorf, G., 1997. On Li-bearing micas: estimating Li from electron microprobe analyses and an improved diagram for graphical representation. Mineral. Mag. 61, 809-834.

Tischendorf, G., Förster, H.-J., Gottesmann, B., 2001. Minor- and trace-element composition of trioctahedral micas: a review. Mineral. Mag. 65, 249-276.

Tucker, R.D., Bradley, D.C., Ver Straeten C.A., Harris, A.G., Ebert, J.R., McCutcheon, S.R., 1998. New U-Pb zircon ages and the duration and division of Devonian time. 
Earth Planet. Sci. Lett. 158, 175-186.

Turner, F.J., 1981. Metamorphic petrology. New York, McGraw-Hill, 524 p.

Van Middelaar, W.T., Keith, J.D., 1990. Mica chemistry as an indicator of oxygen and halogen fugacities in the CanTung and other W-related granitoids in the North American Cordillera. In: Stein, H.J., Hannah, J.L. (Ed.), Ore-bearing granite systems; Petrogenesis and mineralizing process. Geol. Soc. Am., Special Paper 246, 205-220.

Watson, E.B., Harrison, T.M., 1983. Zircon saturation revisited: temperature and composition effects in a variety of crustal magma types. Earth Planet. Sci. Lett. 64, 295-304.

Webster, J.D., 1997a. Exsolution of magmatic volatile phases from Cl-enriched mineralizing granitic magmas and implications for ore metal transport. Geochim. Cosmochim. Acta 61, 1017-1029.

Webster, J.D., 1997b. Chloride solubility in felsic melts and the role of chloride in magmatic degassing. J. Petrol. 38, 1793-1807.

Whalen, J.B., 1993. Geology, petrography and geochemistry of Appalachian granites in New Brunswick and Gaspésie, Quebec. Geol. Surv. Can. Bull. 436, 130 p.

Whalen, J.B., Jenner, G.A., Longstaffe, F.J., Hegner, E., 1996. Nature and evolution of the eastern margin of Iapetus: geochemical and isotopic constraints from SiluroDevonian granitoid plutons in the New Brunswick Appalachians. Can. J. Earth Sci. $33,140-155$.

William-Jones, A.E., Heinrich, C.A., 2005. Vapor transport of metals and the formation of magmatic-hydrothermal ore deposits. Econ. Geol. 100, 1287-1312. 
Wones, D.R., Eugster, H.P., 1965. Stability of biotite: experiment, theory, and application. Am. Mineral. 50, 1228-1272.

Wood, S.A., 1992. Experimental determination of the solubility of $\mathrm{WO}_{3}$ and the thermodynamic properties of $\mathrm{H}_{2} \mathrm{WO}_{4}(\mathrm{aq})$ in the range $300-600{ }^{\circ} \mathrm{C}$ at 1 kbar: Calculation of scheelite solubility. Geochim. Cosmochim. Acta 56, 1827-1836.

Wood, S.A., Samson, I.M., 1998. Solubility of ore minerals and complexation of ore metals in hydrothermal solutions. Rev. Econ. Geol. 10, 33-80.

Wood, S.A., Samson, I.M., 2000. The hydrothermal geochemistry of tungsten in granitoid environments: I. Relative Solubilities of Ferberite and Scheelite as a function of T, P, $\mathrm{pH}$, and $\mathrm{m}_{\mathrm{NaCl}}$. Econ. Geol. 95, 143-182.

Wood, S.A., Vlassopoulos, D., 1989. Experimental determination of the hydrothermal solubility and speciation of tungsten at $500{ }^{\circ} \mathrm{C}$ and $1 \mathrm{kbar}$. Geochim. Cosmochim. Acta 53, 303-312.

Yang, X.M., Lentz, D.R., Chi, G.X., 2002. Petrochemistry of Lake George granodiorite stock and related gold mineralization, York County, New Brunswick. Geological Survey of Canada, Current Research D7, $10 \mathrm{p}$.

Yang, X.M., Lentz, D.R., McCutcheon, S.R., 2003. Petrochemical evolution of subvolcanic granitoid intrusions within the Late Devonian Mount Pleasant Caldera, southwestern New Brunswick, Canada: comparison of Au versus SN-W-Mopolymetallic mineralization systems. Atlantic Geol. 39, 97-121.

Yang, X.M., Lentz, D.R., 2005. Chemical composition of rock-forming minerals in goldrelated granitoid intrusions, southwestern New Brunswick, Canada: implications for crystallization conditions, volatile exsolution, and fluorine-chlorine activity. Contrib. 
Mineral. Petrol. 150, 287-305.

Yang, X.M., Lentz, D.R., Chi, G.X. and Thorne, K.G., 2008. Geochemical characteristics of gold-related granitoids in southwestern New Brunswick, Canada. Lithos 104, $355-377$.

Yokoi, K., Matsubayashi, N., Miyanaga, T., Watanabe, I., Ikeda, S., 1993. Studies on the structure of molybdenum (VI) in acidic solution by XANES and EXAFS. Polyhedron 12, 911-914.

Zhang. W., 2015. Petrological and metallogenic studies of the Nashwaak Granite and felsic dykes associated with the Sisson Brook W-Mo-Cu deposit, west-central New Brunswick, Canada. Ph. D. Thesis, unpublished.

Zhu, C., Sverjensky, D.A., 1991. Partitioning of F-Cl-OH between minerals and hydrothermal fluids. Geochim. Cosmochim. Acta 55, 1837-1858.

Zhu, C., Sverjensky, D.A., 1992. F-Cl-OH partitioning between biotite and apatite. Geochim. Cosmochim. Acta 56, 3435-3467. 


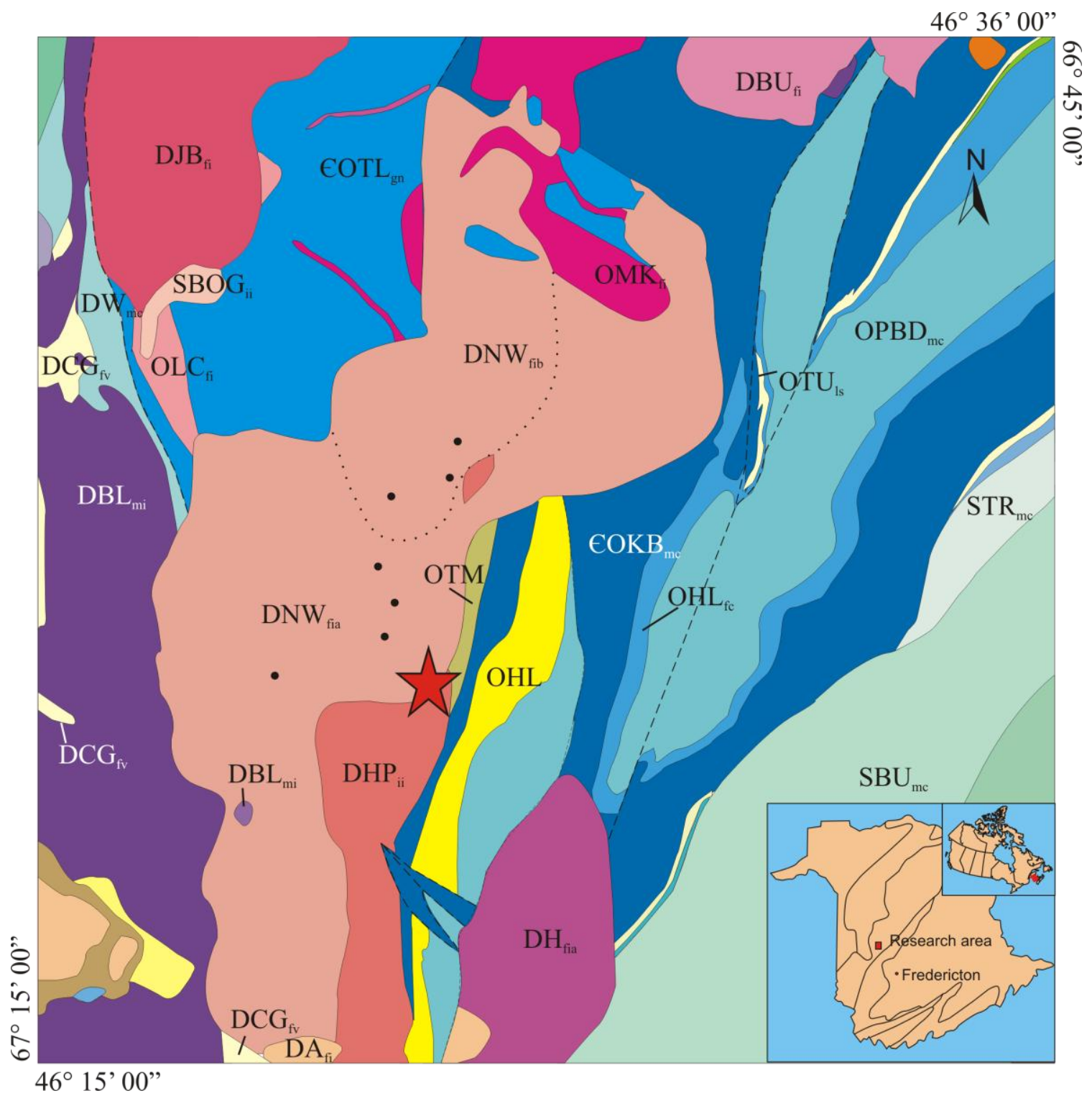

Fig. 1 Regional geological map showing the distribution of the Nashwaak Granites (scale: 1:50 000) and location of the Sisson Brook W-Mo-Cu deposit (Smith and Fyffe, 2006a, b). Cambrian to Early Ordovician: COTL $_{\mathrm{gn}}$ - Trousers Lake Metamorphic Suite, $\mathrm{COKB}_{\mathrm{mc}}$, - Miramichi Group; Ordovician: $\mathrm{OLC}_{\mathrm{fi}}$ - Little Clearwater Brook Granite, $\mathrm{OMK}_{\mathrm{fi}}$ - McKiel Lake Granite, OPBD, OHL Group; Silurian: $\mathrm{SCR}_{\mathrm{fc}}, \mathrm{SBU}_{\mathrm{mc}}, \mathrm{STR}_{\mathrm{mc}}, \mathrm{SSM}_{\mathrm{fc}}, \mathrm{SBOG}_{\mathrm{ii}}$; Devonian: $\mathrm{DH}_{\mathrm{fia}}-$ Hawkshaw Granite, $\mathrm{DBL}_{\mathrm{mi}}$ - Becaguimec Lake Gabbro, $\mathrm{DHP}_{\mathrm{ii}}$ - Howard Peak Granodiorite, DNW fia

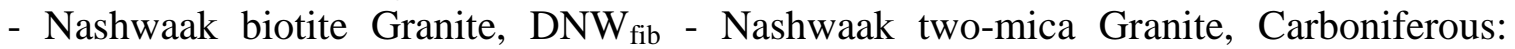
$\mathrm{CCL}_{\mathrm{cc}}, \mathrm{CHRmv}, \mathrm{CSN}_{\mathrm{cc}}-$ Mabou Group, $\mathrm{CMO}_{\mathrm{mc}}$ - Pictou Group; ------ Fault, $\bullet$ location of pluton samples, dyke samples are from star area around the Sisson Brook W-Mo-Cu deposit (see Fig. 2). 


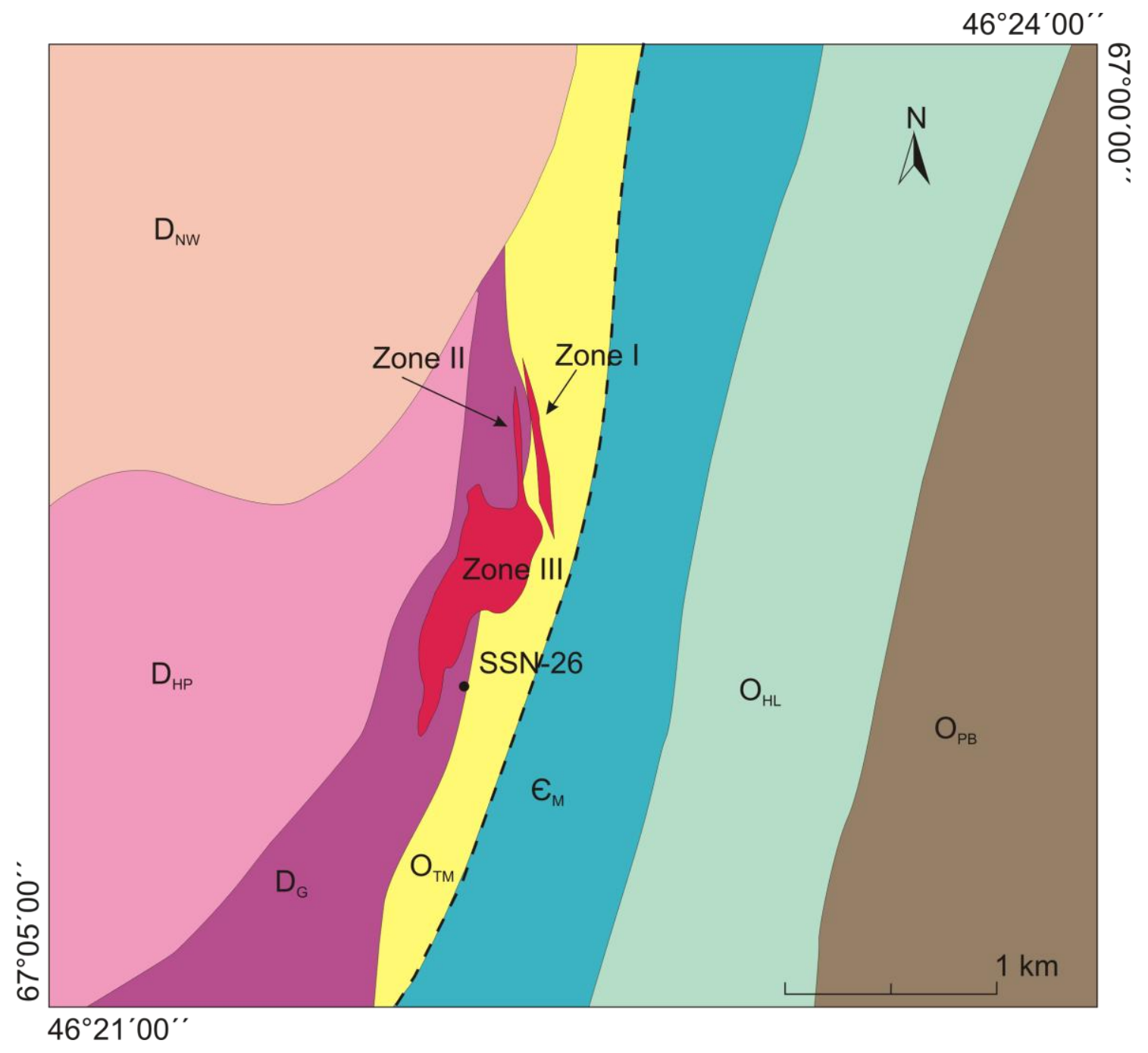

Fig. 2 Geological map of the local area around the Sisson Brook W-Mo-Cu deposit (Fyffe et al., 2008). D $\mathrm{NW}_{\mathrm{N}}$ Devonian Nashwaak Granite, $\mathrm{D}_{\mathrm{HP}}$ Devonian Howard Peak Diorite, $\mathrm{D}_{\mathrm{G}}$ Devonian gabbro, $\mathrm{O}_{\mathrm{PB}}$ Ordovician Push and Be Damned Formation, $\mathrm{O}_{\mathrm{HL}}$ Ordovician Hayden Lake Formation, $\mathrm{O}_{\mathrm{TM}}$ Ordovician Turnbull Mountain Formation, $\mathrm{C}_{\mathrm{M}}$ Cambro-Ordovician Miramichi Group, Dash line - fault. Zone I, II, and III of the deposit are noted. 

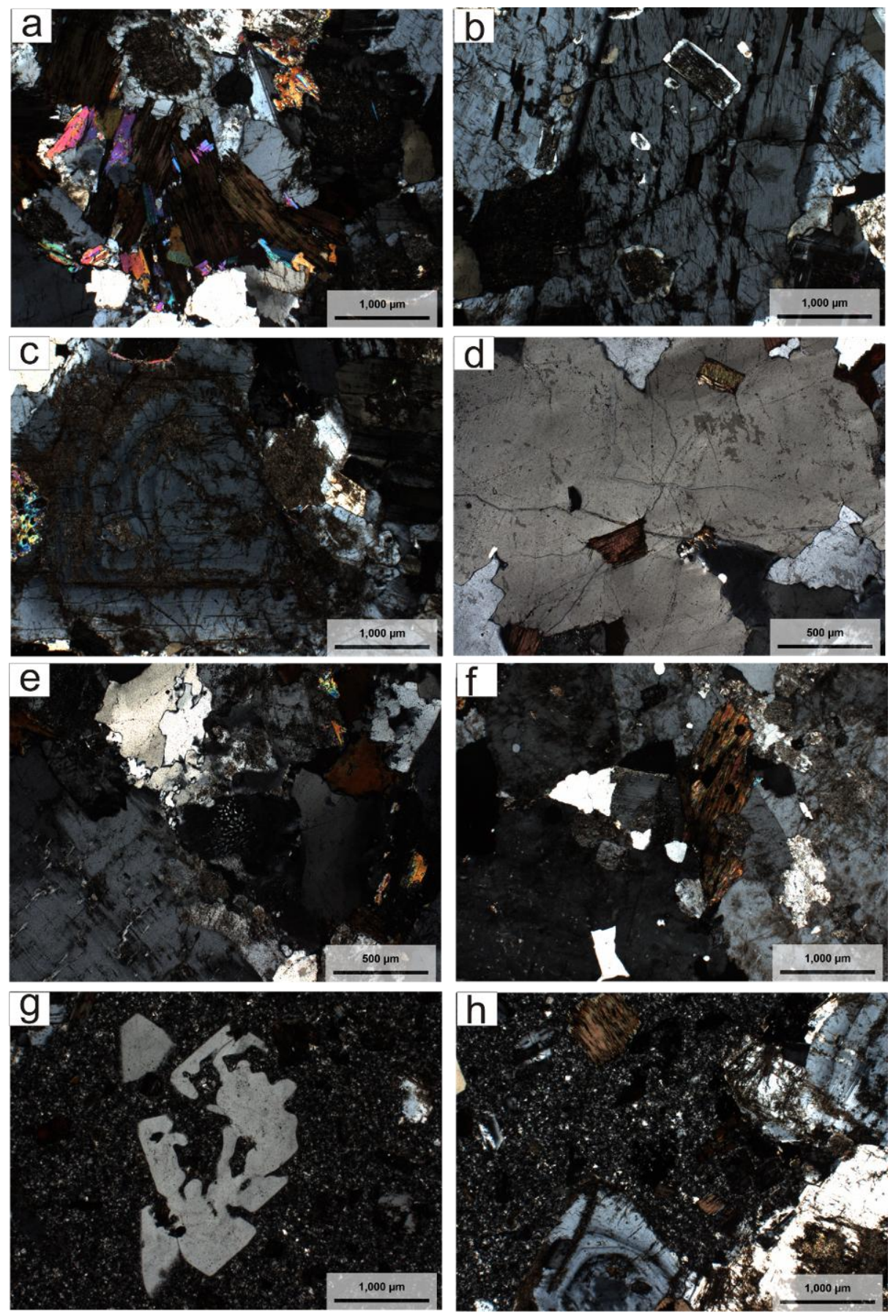

Fig. 3 Representative photomicrographs of texture and mineralogy of the Nashwaak Granites and related dykes. a) muscovite and biotite cluster with a nearby apatite, plagioclase with altered core and magmatic rim, sample MBG5, cross polarized light (XPL); b) plagioclase inclusion in perthite, sample MBG5, XPL; c) plagioclase with zoning, sample MBG5, XPL; d) biotite inclusion in quartz grain, sample BG1, XPL; e) granophyre texture, sample BG1, XPL; f) relative fresh anhydral biotite occur with plagioclase, sample BGD11, XPL; g) skeletal or resorbed quartz phenocryst, sample PD, XPL; h) zoned plagioclase and biotite phenocryst, sample PD, XPL. 

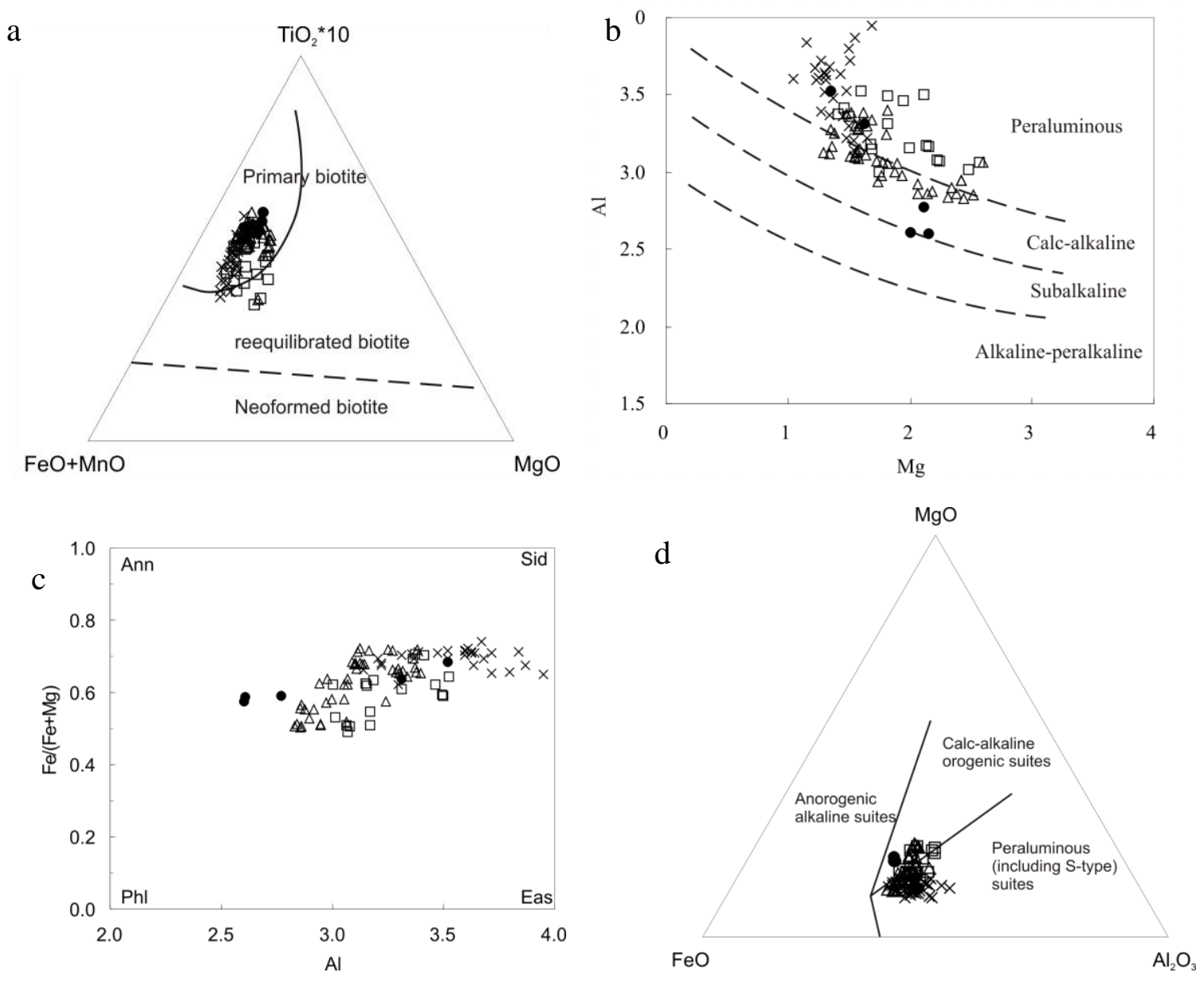

Fig. 4 Chemical compositional diagrams of biotite from the Nashwaak Granites and related dykes. a) Ternary $\mathrm{TiO}_{2}-\mathrm{FeO}+\mathrm{MnO}-\mathrm{MgO}$ diagram after Nachit et al. (2005), b) $\mathrm{Al}-$ $\mathrm{Mg}$ diagram after Stussi and Cuney (1996), c) Fe/(Fe+Mg)-Al diagram after Rieder et al. (1998), d) Ternary $\mathrm{MgO}-\mathrm{FeO}-\mathrm{Al}_{2} \mathrm{O}_{3}$ diagram after Abdel-Rahman (1994) of biotite from Nashwaak Granites and related dykes. $\times$ two mica granite (Group I), $\triangle$ biotite granite (Group II), $\square$ biotite granite dykes (Group III), • porphyry dyke (Group IV). Ann = annite, $\mathrm{Sid}=$ siderophyllite, $\mathrm{Phl}=$ phlogopite, $\mathrm{Pol}=$ polylithionite . 

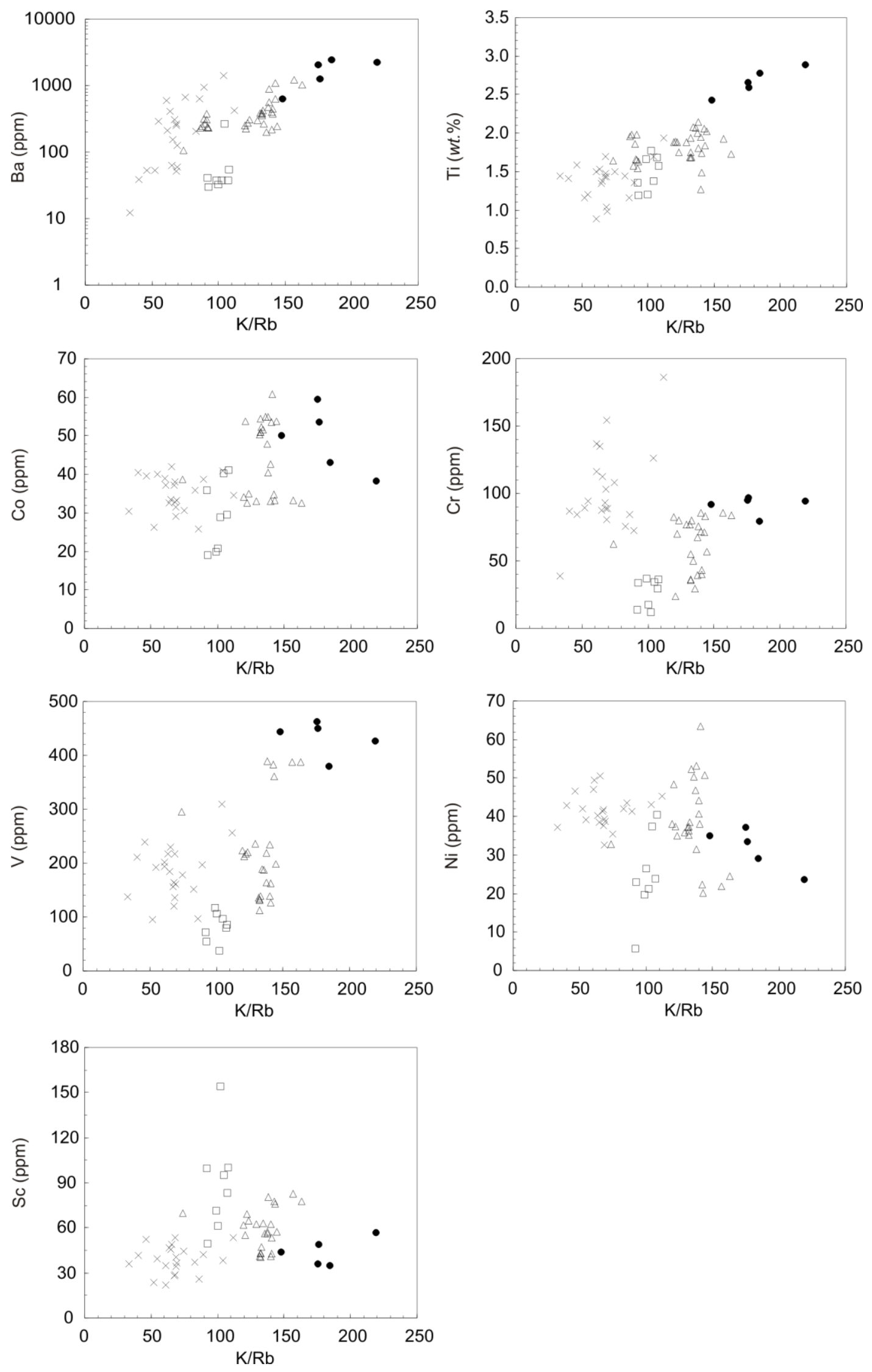

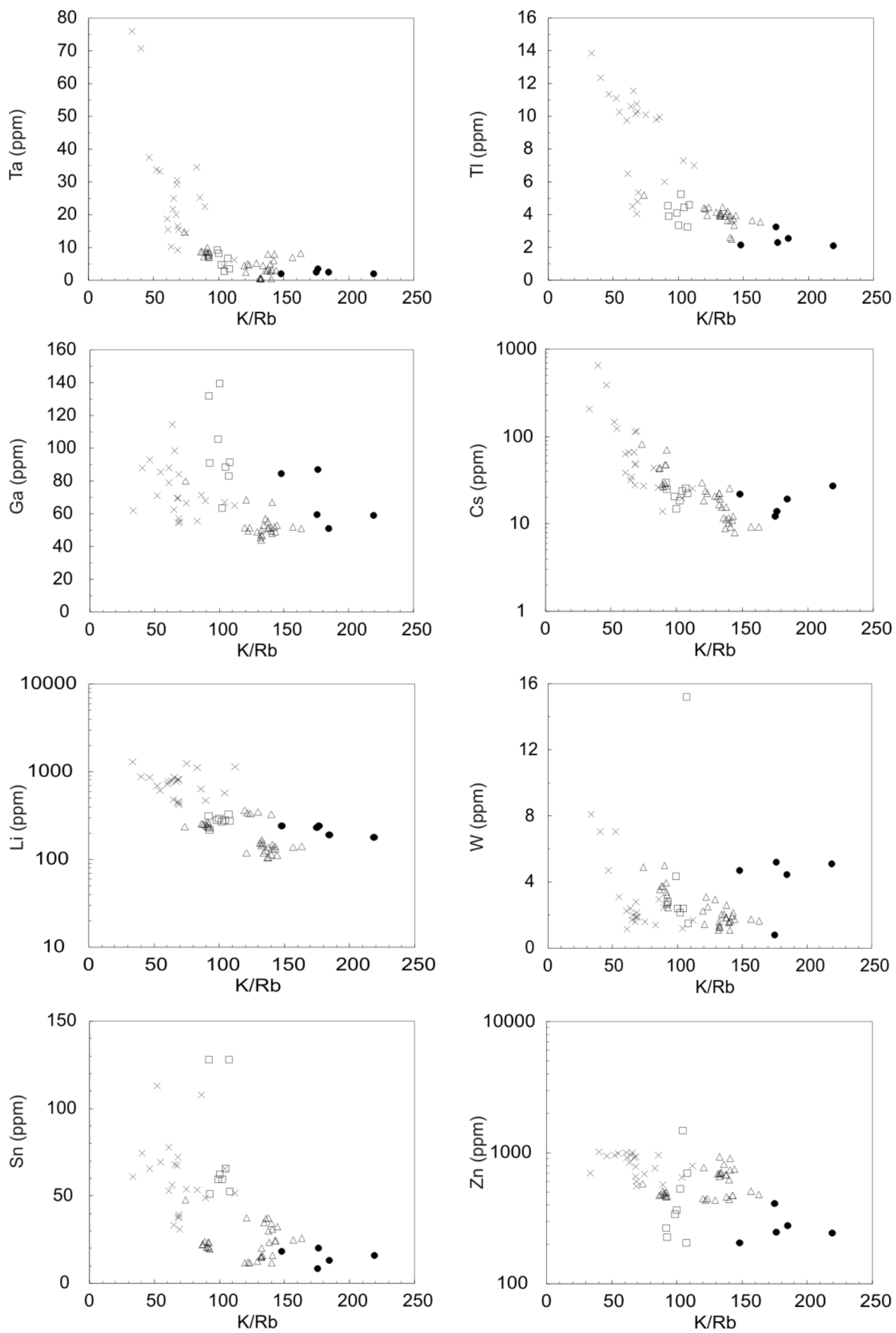

Fig. 5 ( 2 pages) Trace-element composition of biotite from the Nashwaak Granites and related dykes analyzed by LA-ICP-MS. See Fig. 4 for symbols used. 




Fig. 6 Intercept value $\mathrm{IV}(\mathrm{F} / \mathrm{Cl})$ plots against $\mathrm{IV}(\mathrm{F})$ for biotite from the Nashwaak Granites and related dykes. Composition of biotite related to the typical porphyry $\mathrm{Cu}, \mathrm{Sn}$ W-Be, and porphyry Mo deposits are from Munoz (1984). See Fig. 4 for symbols used. 

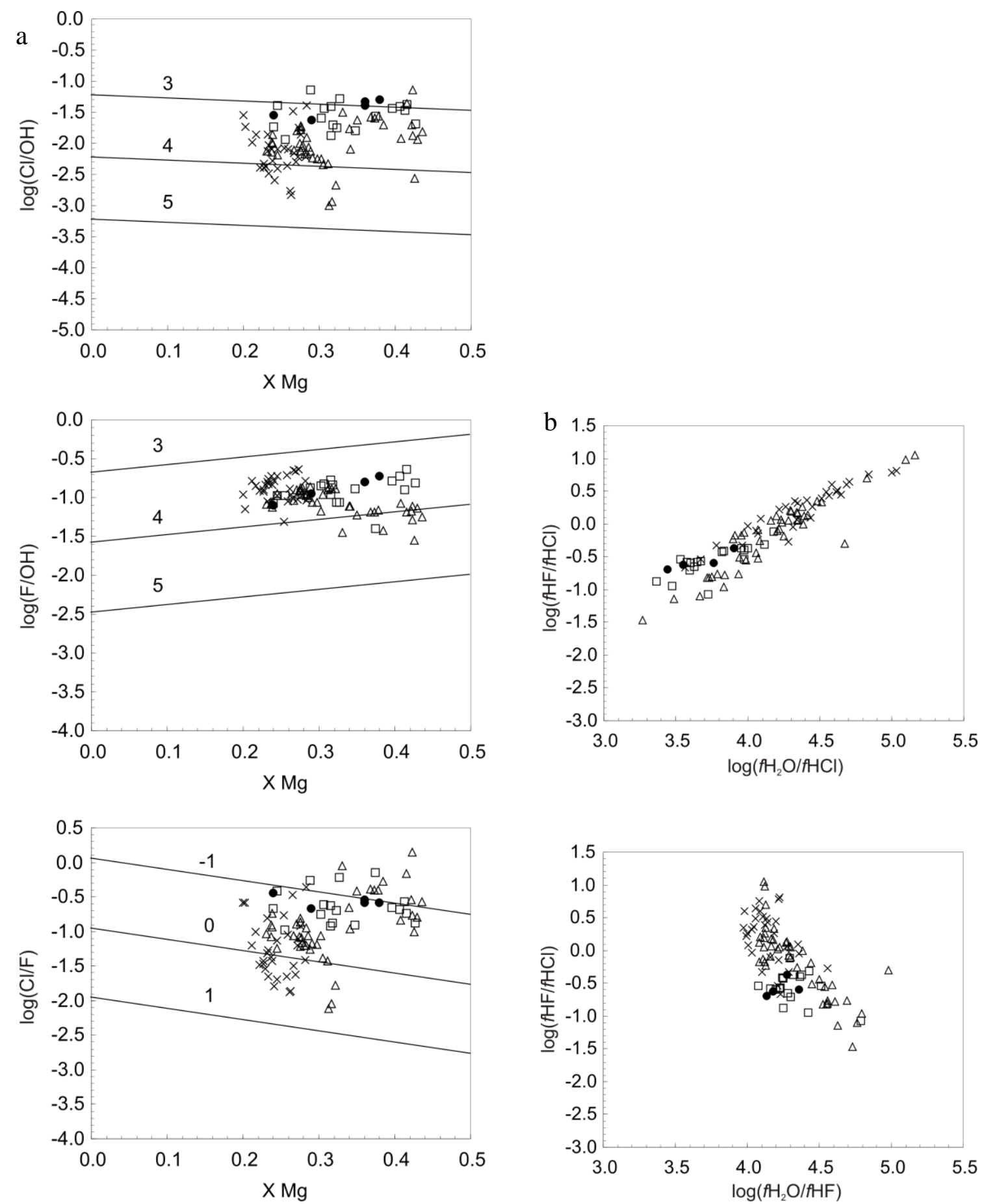

Fig. 7 a) $\log (\mathrm{Cl} / \mathrm{OH}), \log (\mathrm{F} / \mathrm{OH})$, and $\log (\mathrm{Cl} / \mathrm{F})$ vs. $\mathrm{XMg}$ for biotites from the Nashwaak Granites and related dykes. In each diagram, the relative $\log \left(f \mathrm{H}_{2} \mathrm{O} / f \mathrm{HCl}\right), \log \left(f \mathrm{H}_{2} \mathrm{O} / f \mathrm{HF}\right)$, and $\log (f \mathrm{HF} / f \mathrm{HCl})$ reference lines are calculated at $750{ }^{\circ} \mathrm{C}$. b) Detailed $\log \left(f \mathrm{H}_{2} \mathrm{O} / f \mathrm{HCl}\right)$, $\log \left(f \mathrm{H}_{2} \mathrm{O} / f \mathrm{HF}\right)$, and $\log (f \mathrm{HF} / f \mathrm{HCl})$ value of biotite from the Nashwaak Granites and related dykes, these values were calculated based on their relative zircon saturation temperature $\left(\mathrm{T}_{\mathrm{Zr}}\right)$ (Watson and Harrison, 1983). All the calculated formulae are from Munoz (1984, 1992). See Fig. 4 for symbols used. 


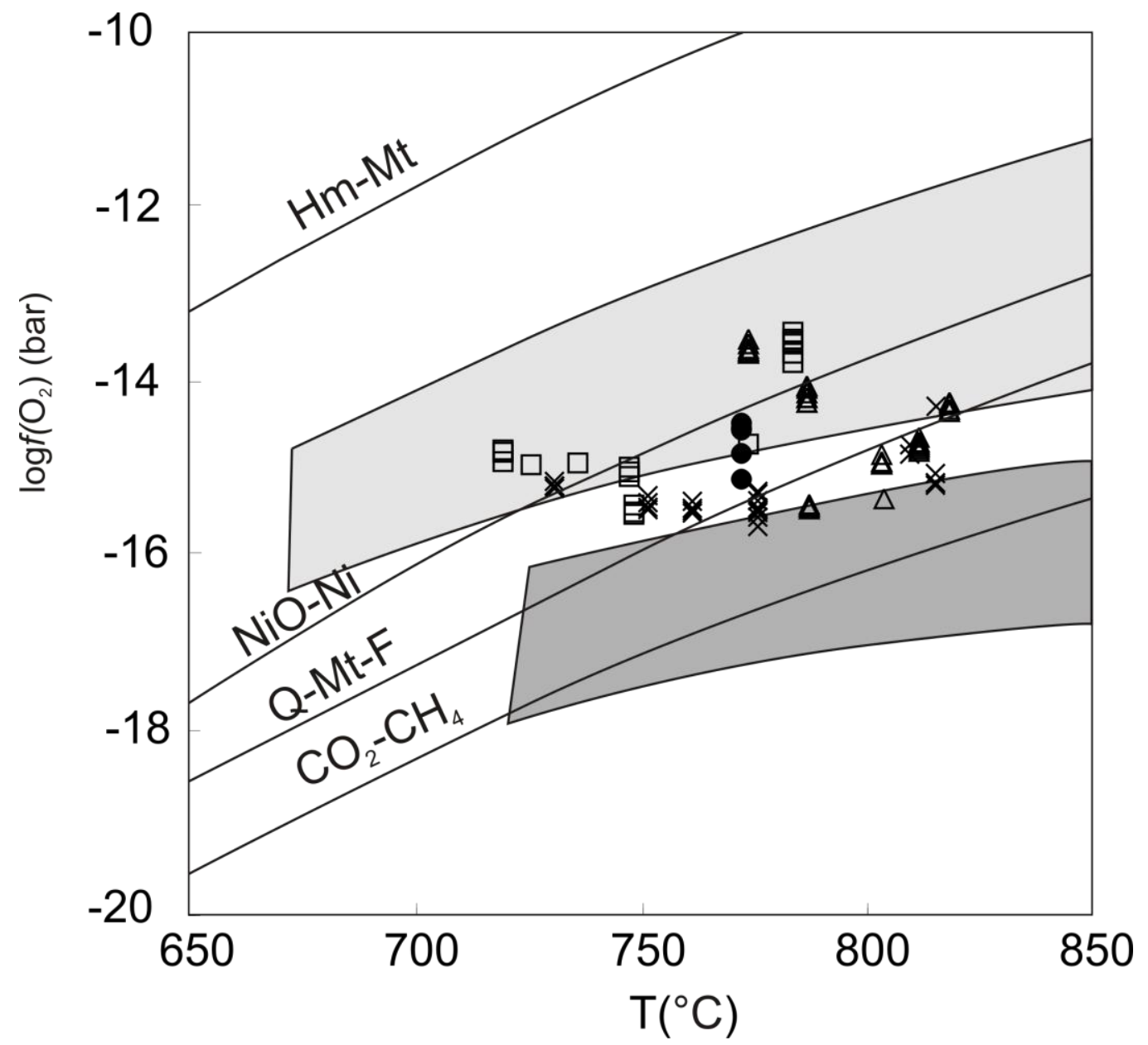

Fig. 8 Temperature vs. oxygen fugacity diagram for biotite from the Nashwaak Granites and related dykes (see Candela, 1989b). See Fig. 4 for symbols used. Light grey pattern denotes contaminated I-type granite. Dark grey pattern represents strongly contaminated reduced I-type granitoids (after Ague and Brimhall, 1988b). 


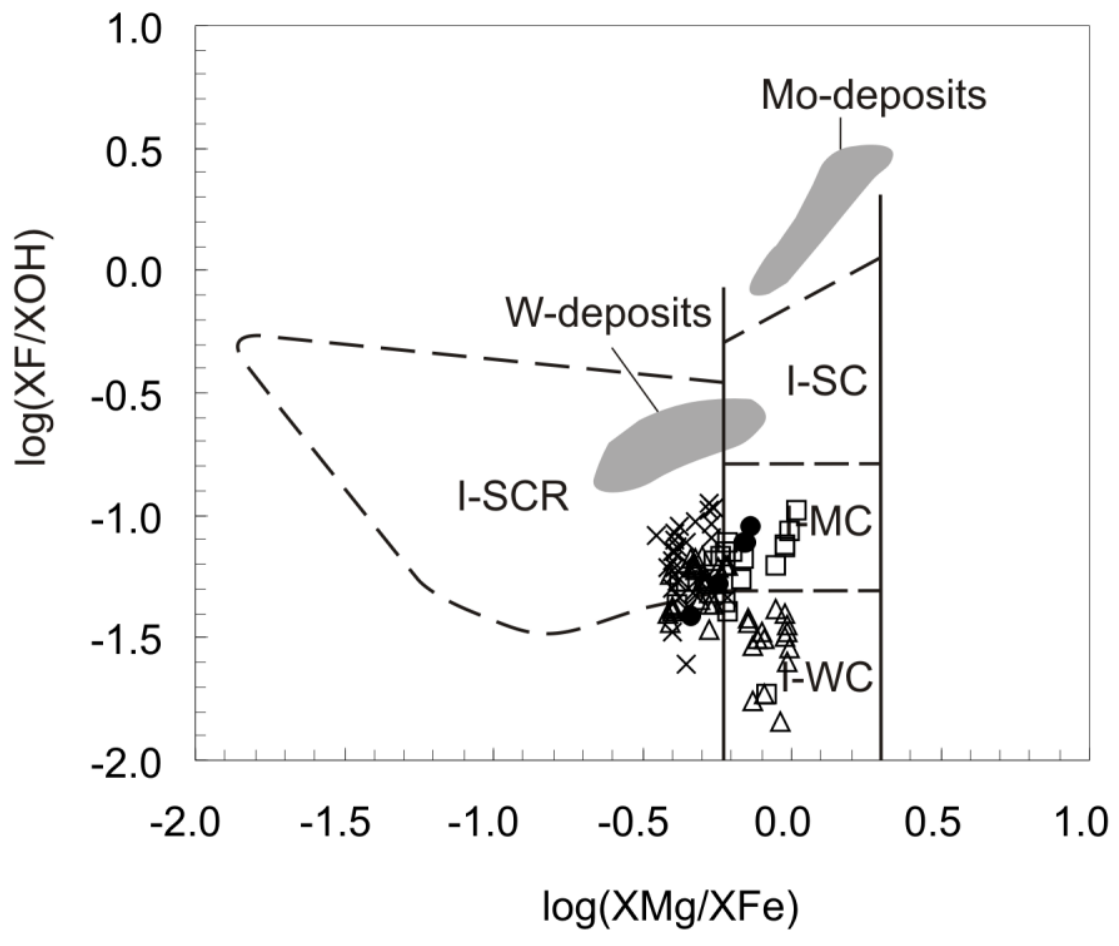

Fig. 9 Classification of the Nashwaak Granites and related dykes according to the composition of their magmatic biotite composition (after Ague and Brimhall, 1988a). For comparison purposes, the biotites related to the Mo- and $\mathrm{W}$-porphyry deposits are also shown after Brimhall and Crerar (1987). I-SC, strongly contaminated I-type; I-MC, moderately contaminated I-type, I-WC, weakly contaminated I-type, I-SCR, strongly contaminated and reduced I-type. See Fig. 4 for symbols used. 
Table 1 Average chemical compositions of biotite from the Nashwaak Granites and related dykes analyzed by electron probe microanalysis (EPMA)

\begin{tabular}{|c|c|c|c|c|c|c|c|c|}
\hline Sample & \multicolumn{2}{|c|}{ Two-mica granite } & \multicolumn{2}{|c|}{ Biotite granite } & \multicolumn{2}{|c|}{ Biotite granitic dykes } & \multicolumn{2}{|c|}{ Porphyry dyke } \\
\hline No. of samples & \multirow{2}{*}{\multicolumn{2}{|c|}{6}} & \multirow{2}{*}{\multicolumn{2}{|c|}{$\frac{7}{44}$}} & \multicolumn{2}{|c|}{7} & \multicolumn{2}{|c|}{1} \\
\hline No. of analyse spots & & & & & & & & \\
\hline & Ave. & $1 \sigma$ & Ave. & $1 \sigma$ & Ave. & $1 \sigma$ & Ave. & $1 \sigma$ \\
\hline $\operatorname{Tzr}\left({ }^{\circ} \mathrm{C}\right)$ & 772 & 28.1 & 796 & 15.4 & 754 & 24.9 & 772 & 0.00 \\
\hline $\mathrm{SiO}_{2}$ & 33.3 & 1.96 & 33.7 & 1.53 & 34.9 & 2.38 & 34.9 & 0.83 \\
\hline $\mathrm{TiO}_{2}$ & 2.75 & 0.53 & 3.51 & 0.46 & 2.59 & 0.50 & 4.03 & 0.38 \\
\hline $\mathrm{Al}_{2} \mathrm{O}_{3}$ & 19.5 & 1.44 & 16.7 & 0.90 & 17.9 & 0.66 & 16.3 & 2.38 \\
\hline $\mathrm{FeO}$ & 23.8 & 2.04 & 22.7 & 2.61 & 22.1 & 2.47 & 22.7 & 0.48 \\
\hline $\mathrm{MgO}$ & 5.96 & 0.58 & 7.70 & 1.54 & 8.40 & 1.65 & 8.07 & 1.48 \\
\hline $\mathrm{MnO}$ & 0.51 & 0.11 & 0.35 & 0.07 & 0.32 & 0.12 & 0.29 & 0.06 \\
\hline $\mathrm{BaO}$ & 0.05 & 0.06 & 0.05 & 0.07 & 0.07 & 0.09 & 0.06 & 0.06 \\
\hline $\mathrm{CaO}$ & 0.12 & 0.16 & 0.05 & 0.06 & 0.18 & 0.40 & 0.04 & 0.02 \\
\hline $\mathrm{ZnO}$ & 0.08 & 0.04 & 0.06 & 0.03 & 0.04 & 0.03 & 0.03 & 0.03 \\
\hline $\mathrm{K}_{2} \mathrm{O}$ & 8.73 & 1.43 & 9.27 & 0.90 & 7.64 & 1.96 & 8.78 & 0.47 \\
\hline $\mathrm{Na}_{2} \mathrm{O}$ & 0.16 & 0.11 & 0.18 & 0.13 & 0.23 & 0.14 & 0.20 & 0.08 \\
\hline $\mathrm{Rb}_{2} \mathrm{O}$ & 0.11 & 0.07 & 0.05 & 0.05 & 0.04 & 0.05 & 0.00 & 0.01 \\
\hline $\mathrm{F}$ & 0.51 & 0.16 & 0.35 & 0.11 & 0.49 & 0.16 & 0.51 & 0.15 \\
\hline $\mathrm{Cl}$ & 0.04 & 0.04 & 0.05 & 0.05 & 0.12 & 0.06 & 0.14 & 0.04 \\
\hline $\mathrm{H}_{2} \mathrm{O}$ & 3.59 & 0.13 & 3.63 & 0.08 & 3.64 & 0.11 & 3.62 & 0.09 \\
\hline $\mathrm{O}=\mathrm{F}$ & -0.22 & 0.07 & -0.15 & 0.05 & -0.20 & 0.07 & -0.22 & 0.06 \\
\hline $\mathrm{O}=\mathrm{Cl}$ & -0.01 & 0.01 & -0.01 & 0.01 & -0.03 & 0.01 & -0.03 & 0.01 \\
\hline Total & 98.9 & 2.06 & 98.2 & 2.02 & 98.5 & 3.09 & 99.7 & 0.65 \\
\hline $\mathrm{Si}$ & 5.18 & 0.19 & 5.30 & 0.18 & 5.37 & 0.19 & 5.36 & 0.11 \\
\hline$A I^{I V}$ & 2.82 & 0.19 & 2.70 & 0.18 & 2.63 & 0.19 & 2.64 & 0.11 \\
\hline Tsite & 8.00 & 0.00 & 8.00 & 0.00 & 8.00 & 0.00 & 8.00 & 0.00 \\
\hline $\mathrm{Ti}$ & 0.32 & 0.06 & 0.42 & 0.05 & 0.30 & 0.06 & 0.46 & 0.04 \\
\hline $\mathrm{Al}^{\mathrm{VI}}$ & 0.75 & 0.25 & 0.40 & 0.11 & 0.62 & 0.13 & 0.32 & 0.33 \\
\hline V & 0.01 & 0.01 & 0.01 & 0.01 & 0.00 & 0.01 & 0.03 & 0.00 \\
\hline $\mathrm{Fe}$ & 3.10 & 0.31 & 2.99 & 0.36 & 2.86 & 0.39 & 2.92 & 0.09 \\
\hline $\mathrm{Mg}$ & 1.39 & 0.15 & 1.81 & 0.36 & 1.92 & 0.34 & 1.85 & 0.35 \\
\hline $\mathrm{Mn}$ & 0.07 & 0.01 & 0.05 & 0.01 & 0.04 & 0.02 & 0.04 & 0.01 \\
\hline $\mathrm{Zn}$ & 0.01 & 0.00 & 0.01 & 0.00 & 0.00 & 0.00 & 0.00 & 0.00 \\
\hline O site & 5.65 & 0.21 & 5.67 & 0.14 & 5.75 & 0.25 & 5.63 & 0.11 \\
\hline $\mathrm{Ca}$ & 0.02 & 0.03 & 0.01 & 0.01 & 0.03 & 0.07 & 0.01 & 0.00 \\
\hline $\mathrm{K}$ & 1.74 & 0.29 & 1.86 & 0.18 & 1.49 & 0.35 & 1.72 & 0.08 \\
\hline $\mathrm{Na}$ & 0.05 & 0.03 & 0.05 & 0.04 & 0.07 & 0.04 & 0.06 & 0.02 \\
\hline$F$ & 0.25 & 0.08 & 0.17 & 0.05 & 0.24 & 0.07 & 0.25 & 0.07 \\
\hline $\mathrm{Cl}$ & 0.01 & 0.01 & 0.01 & 0.01 & 0.03 & 0.01 & 0.04 & 0.01 \\
\hline $\mathrm{OH}$ & 3.74 & 0.08 & 3.81 & 0.05 & 3.73 & 0.07 & 3.71 & 0.09 \\
\hline $\mathrm{Al}$ & 3.57 & 0.24 & 3.10 & 0.17 & 3.25 & 0.18 & 2.96 & 0.42 \\
\hline$X_{M g}$ & 0.25 & 0.02 & 0.32 & 0.06 & 0.33 & 0.06 & 0.33 & 0.06 \\
\hline$X_{\text {Sid }}$ & 0.67 & 0.06 & 0.50 & 0.10 & 0.51 & 0.09 & 0.45 & 0.15 \\
\hline $\mathrm{X}_{\mathrm{An}}$ & 0.09 & 0.05 & 0.18 & 0.04 & 0.15 & 0.05 & 0.22 & 0.10 \\
\hline $\mathrm{IV}(\mathrm{F})$ & 1.73 & 0.16 & 2.03 & 0.23 & 1.90 & 0.16 & 1.87 & 0.06 \\
\hline $\mathrm{IV}(\mathrm{Cl})$ & -2.77 & 0.34 & -3.06 & 0.42 & -3.52 & 0.26 & -3.62 & 0.24 \\
\hline $\log \left(\mathrm{fH}_{2} \mathrm{O}\right) /(\mathrm{fHF})$ & 4.15 & 0.13 & 4.34 & 0.24 & 4.32 & 0.16 & 4.23 & 0.09 \\
\hline $\log \left(\mathrm{fH}_{2} \mathrm{O}\right) /(\mathrm{fHCl})$ & 4.36 & 0.36 & 4.16 & 0.37 & 3.76 & 0.23 & 3.64 & 0.19 \\
\hline $\log (\mathrm{fHF} / \mathrm{fHCl})$ & 0.22 & 0.39 & -0.18 & 0.53 & -0.56 & 0.24 & -0.58 & 0.12 \\
\hline
\end{tabular}

Notes: Formula calculations are based on 22 oxygen, $\mathrm{OH}$ is calculated by $\mathrm{OH}=4-(\mathrm{Cl}+\mathrm{F})$, Intercept value IV(F), IV (Cl) and halogen fugacity are calculated by Munoz $(1984,1992)$. $\mathrm{T}_{\mathrm{zr}}$ were calculated by Watson and Harrison (1983). Complete data see Appendix Table A. 
Table 2 Average content of trace elements in biotite from Nashwaak Granites and related dykes analyzed by the laser ablation-inductively coupled plasma-mass spectrometry (LAICP-MS).

\begin{tabular}{|c|c|c|c|c|c|c|c|c|c|c|c|c|}
\hline & MBG & Int2SE & LOD & $B G$ & Int2SE & LOD & $B G D$ & Int2SE & LOD & $\mathrm{PD}$ & Int2SE & LOD \\
\hline \multicolumn{13}{|c|}{ wt. \% } \\
\hline $\mathrm{Si}$ & 16.3 & 0.28 & 870 & 16.9 & 0.27 & 636 & 16.6 & 0.31 & 516 & 19.0 & 0.31 & 302 \\
\hline $\mathrm{Ti}$ & 1.39 & 0.02 & 4.85 & 1.81 & 0.03 & 4.64 & 1.48 & 0.03 & 3.58 & 2.67 & 0.08 & 10.4 \\
\hline $\mathrm{Fe}$ & 17.2 & 0.28 & 19.5 & 16.1 & 0.26 & 17.7 & 17.5 & 0.33 & 17.5 & 20.5 & 0.46 & 35.1 \\
\hline $\mathrm{Mn}$ & 0.43 & 0.01 & 2.25 & 0.29 & 0.00 & 1.74 & 0.31 & 0.01 & 1.55 & 0.31 & 0.01 & 1.48 \\
\hline $\mathrm{Mg}$ & 3.39 & 0.05 & 4.29 & 4.47 & 0.06 & 5.42 & 4.21 & 0.06 & 6.13 & 6.20 & 0.11 & 11.2 \\
\hline $\mathrm{Ca}$ & 0.09 & 0.02 & 238 & 0.25 & 0.03 & 198 & 1.91 & 0.20 & 117 & 1.53 & 0.09 & 63.5 \\
\hline $\mathrm{Na}$ & 0.05 & 0.00 & 10.0 & 0.11 & 0.00 & 8.26 & 0.09 & 0.01 & 4.70 & 0.11 & 0.00 & 2.33 \\
\hline $\mathrm{K}$ & 8.03 & 0.13 & 10.8 & 8.55 & 0.14 & 13.6 & 6.37 & 0.11 & 9.09 & 7.55 & 0.14 & 23.4 \\
\hline \multicolumn{13}{|c|}{ ppm } \\
\hline $\mathrm{Li}$ & 766 & 12.5 & 2.98 & 198 & 4.44 & 2.51 & 281 & 6.76 & 1.21 & 217 & 4.42 & 0.11 \\
\hline $\mathrm{Be}$ & 6.10 & 0.95 & 0.11 & 0.30 & 0.22 & 0.23 & 6.48 & 1.04 & 0.08 & 2.45 & 0.65 & 0.06 \\
\hline $\mathrm{Rb}$ & 1270 & 22.8 & 0.60 & 728 & 13.0 & 0.45 & 632 & 10.9 & 0.22 & 423 & 8.04 & 0.14 \\
\hline $\mathrm{Sr}$ & 4.89 & 0.32 & 0.08 & 2.63 & 0.25 & 0.06 & 14.1 & 0.87 & 0.02 & 13.0 & 0.36 & 0.00 \\
\hline $\mathrm{Ba}$ & 329 & 6.26 & 0.46 & 407 & 6.88 & 0.39 & 67.2 & 1.59 & 0.15 & 1732 & 28.0 & 0.35 \\
\hline Cs & 105 & 2.39 & 0.13 & 24.4 & 0.62 & 0.10 & 22.5 & 0.53 & 0.05 & 18.9 & 0.52 & 0.01 \\
\hline $\mathrm{Ga}$ & 73.8 & 1.80 & 0.98 & 52.9 & 1.51 & 1.02 & 99.3 & 1.99 & 0.37 & 68.3 & 1.52 & 0.02 \\
\hline TI & 8.97 & 0.28 & 0.04 & 3.91 & 0.17 & 0.05 & 4.18 & 0.13 & 0.02 & 2.48 & 0.09 & 0.01 \\
\hline $\mathrm{Ta}$ & 25.9 & 0.57 & 0.03 & 5.32 & 0.14 & 0.02 & 6.26 & 0.16 & 0.01 & 2.50 & 0.10 & 0.00 \\
\hline Sc & 38.8 & 1.13 & 0.91 & 59.3 & 1.29 & 1.03 & 89.2 & 2.29 & 0.26 & 44.1 & 1.85 & 0.06 \\
\hline $\mathrm{V}$ & 184 & 3.20 & 0.67 & 223 & 3.34 & 0.72 & 81.4 & 1.79 & 0.22 & 433 & 8.16 & 0.23 \\
\hline $\mathrm{Cr}$ & 102 & 2.12 & 1.61 & 62.6 & 1.78 & 1.64 & 26.8 & 0.97 & 1.05 & 91.4 & 1.80 & 0.84 \\
\hline Co & 35.0 & 0.92 & 0.49 & 44.5 & 1.11 & 0.50 & 29.4 & 0.79 & 0.15 & 48.9 & 1.15 & 0.02 \\
\hline $\mathrm{Ni}$ & 41.6 & 2.16 & 2.52 & 38.9 & 2.28 & 2.85 & 24.7 & 1.28 & 0.80 & 31.7 & 1.12 & 0.08 \\
\hline $\mathrm{Cu}$ & 6.35 & 0.68 & 0.59 & 7.08 & 0.67 & 0.67 & 6.66 & 1.17 & 0.22 & 5.13 & 1.42 & 0.04 \\
\hline $\mathrm{Zn}$ & 828 & 14.9 & 1.85 & 584 & 11.1 & 1.52 & 514 & 62.3 & 0.76 & 276 & 4.18 & 0.18 \\
\hline Mo & 0.27 & 0.47 & 1.21 & 0.30 & 0.35 & 0.94 & 0.09 & 0.16 & 0.38 & 0.60 & 0.04 & 0.00 \\
\hline Sn & 60.9 & 1.53 & 0.23 & 23.5 & 0.89 & 0.19 & 75.8 & 4.58 & 0.10 & 15.2 & 0.47 & 0.04 \\
\hline W & 2.86 & 0.16 & 0.06 & 2.39 & 0.13 & 0.05 & 4.18 & 0.27 & 0.01 & 4.05 & 0.28 & 0.00 \\
\hline
\end{tabular}

Note: Stochiometric Al content for each spot measured by EMPA is used for internal standardization. Int2SE is analytical error. LOD is limit of detection which is shown in ppm for all the elements. Complete data see Appendix Table D. 